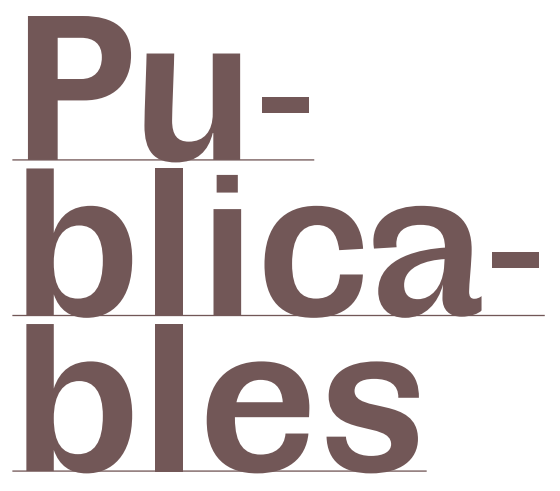

Pub-

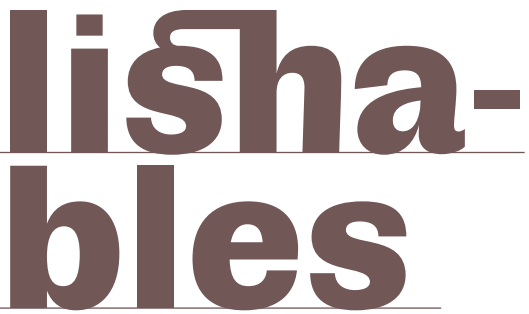

○
COVENTRY UNIVERSITY CENTRE FOR POSTDIGITAL CULTURES

COVENTRY, INGLATERRA

kieseweh@coventry.ac.uk
Rebekka Kresemetter

-
COVENTRY UNIVERSITY CENTRE FOR POSTDIGITAL CULTURES

COVENTRY, ENGLAND

kieseweh@coventry.ac.uk

\begin{tabular}{|c|c|c|}
\hline \begin{tabular}{l|l} 
ISEÑA & 16
\end{tabular} & ENE & 2020 \\
\hline \multicolumn{3}{|c|}{ ISSN } \\
\hline $\begin{array}{l}\text { o718-8447 } \\
\text { (impreso) }\end{array}$ & $\begin{array}{l}245 \\
\text { (ele }\end{array}$ & $\begin{array}{l}\text { 2-4298 } \\
\text { trónico) }\end{array}$ \\
\hline
\end{tabular}

COPYRIGHT: CC BY-SA $3.0 \mathrm{CL}$

Artículo

de investigación original

Recepción 10 Nov 2019

Aceptación 23 DIC 2019

Cómo citar este artículo:

Kiesewetter, R. (2020).

Publicables.

Diseña, (16), 58-87.

https:// doi.org/10.7764/

disena.16.58-87

Traducción: José Miguel Neira

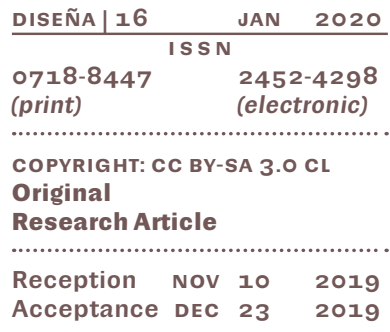

How to cite this article:

Kiesewetter, R. (2020).

Publishables.

Diseña, (16), 58-87.

https://doi.org/10.7764/

disena.16.58-87 


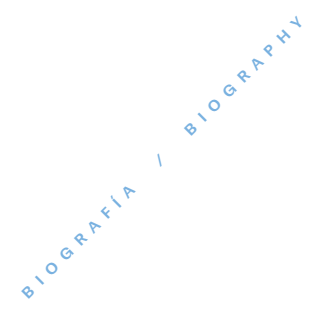

Rebekka Kiesewetter Licenciada (MA) en Historia del Arte, Economía e Historia Moderna, Universidad de Zúrich. Actualmente cursa un doctorado titulado "Publicación de acceso abierto como espacio disputado" en el Centre for Postdigital Cultures de la Universidad de Coventry. Es investigadora asociada en el Sandberg Institut de Ámsterdam. Su investigación aborda la publicación de acceso abierto; las dimensiones filosóficas y políticas de la apertura; la dimensión material, relacional y performativa de las publicaciones; y las críticas feministas e interseccionales de la producción de conocimiento académico. Ha sido profesora visitante y docente invitada en la Academia de Arte y Diseño FHnw, la Universidad de las Artes de Berna y en el Programa de Experimentación de Artes Políticas (S PEAP) en Sciences Po, entre otras instituciones. Es coautora de "Annotating Publishing. Publishing as Institutent Practice" (con L. Kolb; Critical Media Lab HG K F HNw Basel, 2019) y es coeditora de Šibenik Alternating Currents. Publishing Acts II (con A. D. Beroš y E. Jurcan; Dpr-Barcelona, 2019).
Rebekka Kiesewetter Lic. Phil. I (MA) in Art History, Economics, and Modern History, University of Zurich. She is currently doing a PhD titled 'Open Access Publishing as a Contested Space' at the Centre for Postdigital Cultures at Coventry University. She is a Research Associate at the Sandberg Institut in Amsterdam. Her research addresses Open Access Publishing; the philosophical and political dimensions of openness; the material, relational, and performative dimension of publishing and publications; and feminist and intersectional critiques of academic knowledge production. She has been Visiting Professor and Guest Lecturer at the FHNW Academy of Art and Design, University of the Arts Bern, and the Political Arts Experimentation Program (SPEAP) at Sciences Po, among other institutions. She is co-author of 'Annotating Publishing. Publishing as Institutent Practice' (with L. Kolb; Critical Media Lab HG K FH NW Basel, 2019) and co-editor of Šibenik Alternating Currents. Publishing Acts II (with A. D. Beroš and E. Jurcan, Dpr-Barcelona, 2019). 
RESUMEN ESte articulo aborda la publicación académica - de acceso abierto - como herramienta. Por un lado, en relación a una industria editorial comercial que liga las desigualdades en el proceso de legitimación institucional de los conocimientos con una visión neoliberal, competitiva e individualista del mundo; y también respecto a los modelos que actualmente siguen las iniciativas politicas y de financiamiento que consideran la publicación de acceso abierto como un modelo de negocios, que capitaliza a partir de las desigualdades de género, clase y raza arraigadas en los sistemas de producción de conocimiento académico. Por otro lado, se revisan

Publicación de acceso abierto

Prácticas de conocimiento

Relacionalidad

Hacer como critica

Publicación performática
Palabras clave:

las tendencias que siguen algunas iniciativas editoriales de acceso abierto dirigidas por académicos que utilizan la publicación como base para una práctica intervencionista orientada a perturbar - conceptual, formal y organizacionalmente- los marcos institucionales y neoliberales de producción y comunicación del conocimiento académico. Estas iniciativas se discuten y contextualizan a través de secciones más especulativas desplegadas en torno a epistemologias feministas e interseccionales, destacando el carácter performativo, material y relacional del acto de publicary las publicaciones. Asi, este texto señala, performativamente, posibles nuevos formatos, actividades e instituciones, así como diferentes perspectivas para y sobre la publicación, las que podrian resultar instrumentales para instanciar modos académicos más horizontales e inclusivos de producción de conocimiento.

ABSTRAGT This article discusses academic (Open Access) publishing as a tool. On the one hand, with regards to a commercial publishing industry that ties in its inequalities in the institutional legitimation of knowledges with a neoliberal, competitive, and individualizing world view; as well as with regards to current models of policy and funding driven initiatives considering Open Access (OA) publishing as a business capitalizing on inequalities based on gender, class, and race embedded in systems of scholarly knowledge production. On the other hand, this article reviews current strands

Keywords:

Open Access publishing

Knowledge practices

Relationality

Making as critique

Performative publishing of scholar-led OA publishing initiatives that use publishing as a base for an interventionist practice geared at unsettling institutional and neoliberal frameworks of scholarly knowledge production and communication - conceptionally, formally, and organizationally. These initiatives are discussed within more speculative text sections unfolding around feminist and intersectional epistemologies, highlighting the performative, material, and relational character of publishing and publications. Thereby, this text aims to performatively point out possible different publishing formats, activities, and institutions, as well as different perspectives for and on publishing that might be instrumental for instantiating more horizontal and inclusive scholarly forms of knowledge production. 
Por mucho que domines una herramienta, esta te dominará. Las herramientas que recibimos no están destinadas a liberarnos. No utilizamos nuestras herramientas en toda su capacidad. Porque no sabemos cómo realizar los movimientos que no hemos practicado desde hace mucho tiempo (o que aún no hemos practicado); porque es peligroso. Porque tenemos miedo de perder esa pizca de control (que todavía podemos persuadirnos de tener); porque tenemos miedo de lastimarnos. Pero ser lastimado - o lastimarse uno mismo, o reconocer que has sido herido, dañado, constantemente-podría ser un requisito previo para probar desde dentro y contra el mundo, un mundo que se ha vuelto profundamente preocupante y problemático, en lo más pequeño y lo más inconmensurable. Un prerrequisito también para combatir en tus luchas actuales, en mis luchas actuales, las contiendas que son tan infinitamente diversas, pero tan comunes a todos.

Este texto trata sobre la publicación (académica) como una herramienta que se inserta en la economía neoliberal del conocimiento impulsada por el mercado y está, además, cruzada por los alcances comerciales de una industria editorial convertida en negocio, lo que la reduce cada vez más, en tanto herramienta, a un medio para promover carreras en función de las condiciones impuestas por un sistema depredador. Sin embargo, como analizaré en las siguientes líneas, el acto de publicar también puede ser usado como una herramienta en el sentido en que Isabelle Stengers la define, esto es, como una tecnología no habitual, no neutral y específica «para pensar a través de lo que está sucediendo» (Stengers, 2005, p. 185); es decir, como una tecnología que hace que una situación específica se convierta en un asunto especial de preocupación; y también como un concepto de práctica que «crea un ángulo desde el cual abordar nuestras posesiones más "serias", incluyendo las ciencias [o los términos en los que opera la publicación académica], como asuntos "extraños", como prácticas extrañas que tendemos a clasificar como supersticiosas» (Stengers \& Bordeleau, 2011, p. 11). Una noción de publi-
As much as you master a tool, it masters you. The tools that we are given are not meant to liberate us. We don't use our tools to their full capacity. Because we don't know how to perform the movements that we have not practiced for too long (or have not yet practiced); because it's dangerous. Because we are afraid of losing that tiny bit of control (that we still can talk ourselves into having); because we are afraid of getting hurt. But getting hurt-or hurting yourself, or acknowledging that you have been hurt, wounded, all along-might be a prerequisite for testing from within and against a world that, in the small and large, has become so deeply troubled and troubling. A prerequisite as well for fighting the ongoing struggles that you fight, that I fight, the struggles that are so infinitely diverse yet in-common.

This text is about (academic) publishing as a tool that, within the market-driven neoliberal knowledge economy and the business scopes of the commercial publishing industry, is increasingly reduced to a means to further careers in accordance with the terms of this predatory system. However, as I will discuss in the following lines, publishing also can be used as a tool in the sense Isabelle Stengers defines it: as a non-habitual, non-neutral, and specific technology "for thinking through what is happening" (Stengers, 2005, p. 185), that is, as a technology that renders a specific situation a matter of particular concern; and also as a concept of practice that "creates an angle from which to approach our most 'serious' holdings including the sciences [or the terms on which academic publishing operates] as 'bizarre,' as bizarre practices that we have the tendency to classify as superstitious" (Stengers \& Bordeleau, 2011, p. 11). A notion of academic publishing derived from Stenger's concept of practice could be seen as a technology prompting us to think instead of to recognize (2005), to take a step back, to hesitate, to question and to reconsider the direction in which 
cación académica derivada del concepto de práctica de Stengers se podría interpretar como una tecnología que nos impulsa a pensar en lugar de reconocer (2005), a dar un paso atrás, a titubear, a cuestionar y reconsiderar la dirección que uno lleva (Ahmed, 2017, pp. 16-17). Por ejemplo, en relación con los formatos utilizados para hacer y comunicar las investigaciones, así como en función de aquello que se vincula a los procesos, las prácticas, los roles y las ambiciones que han evolucionado en torno a ellas, las que incluyen las nociones de autoría, los modelos de publicación, el orden consecutivo y jerárquico de las actividades dentro del proceso de publicación y las expectativas relacionadas con esta (Adema, 2018).

Este texto utiliza la escritura como herramienta. Una herramienta para agarrar, externalizar y probar los pensamientos profundamente pensados, los pensamientos aún no profundamente pensados, Los pensamientos no pensados en abso Luto profundamente, los pensamientos pensados por otros distintos de mí y por mí. Es un ensamblaje inacabado y no exhaustivo, en el cual los fragmentos sólidos de texto se hacen eco y se intercalan con incursiones, pensamientos posteriores, pensamientos inicialesy reconsideraciones, pensamientos repetidos; tenues, débiles, radiantes $\frac{1}{,}$, provisorios: apenas relacionados o aún tratando de relacionarse, de afguna manera, en el contexto de una perspectiva feminista e interseccional so bre Las prácticas académicas de publicación. En cierta medida, este texto organiza y espacializa estos pensamientos, pero más que nada representa un corte: una suspensión temporal (una solución, no en el sentido de una ecuación, sino en el de una sal disuelta $\stackrel{2}{\text { ) }}$ de la actividad interminable de

$$
1
$$

«Un escritor que había encontrado su propia voz presentaba un punto de vista. Creaba significado. El escritor tomó una cierta cantidad de lenguaje, de material verbal, y obligó a ese lenguaje a dejar de irradiarse en múltiples direcciones, incluso innumerables, para irradiar en una sola dirección, para que pudiera ser su propio significado. (...) Una escritura en la que todo tipo de escritura se mezclaba no parecía inmoral, sino amoral, incluso para las masas. Jugó en cada plaza de juegos que encontró; nadie puede hacer eso en una sociedad de clases o jerárquica» (Acker, 1990). No quiero insistir en el significado. En mi significado. O en mi "derecho" a crear significado. La "amoralidad" textual es una puesta a prueba dentro y en contra de un mundo que insiste moralmente en $-\mathrm{y}$ refuerza legalmente - la figura de autoridad de autor independiente e ignora que el pensamiento y el texto siempre existen solo dentro de las relaciones.

2

Mi agradecimiento eterno a Jamie Allen por esto.

one is going (Ahmed, 2017, pp. 16-17). For example, in relation to the formats used to do and commuo nicate research, as well as the processes, practices, roles, and ambitions that have evolved around them, which include the notions of authorship, publishing models, the consecutive and hierarchical order of activities within the publishing process, and expectations connected to publishing (Adema, 2018).

This text uses writing as a tool. As a tool to grasp, externalize, and test thoughts thought through, thoughts not thought throughyet, thoughts not thought at alfyet, thoughts thought by others than myself and myself. It is an unfinished and non-comprehensive assemblage, in which solid pieces of text are echoed by and interspersed with incursions, after-thoughts, first and second thoughts, re-thoughts; faint, feeble, radiating, "1 provisional: Loosely relating or still seeking to get into relation, somehow - against the background of a feminist and intersectional perspective on academic publisfing practices. This text, to a certain extent, arranges and spatializes these thoughts, but more than anything else it represents a cut: a temporary suspension (a solution not in the sense of an equation, but in the sense of a dissolved salt $\mathbf{t}^{2}$ ) of a never ending activity of coming to terms with a topic; a material, aesthetic, or ethical resolution (Barad, 1997) of the relational and multi-vocal activity of research, writing, and publishing, in order to enable others to join the dialogue. Writing, for me, is also a tool to make encounters - with those (human or not) around me, before and after me; with the materiality of thought and text, writing and publishing; with 1

"A writer who had found his own voice presented a viewpoint. Created meaning. The writer took a certain amount of language, verbal material, forced that language to stop radiating in multiple, even innumerable directions, to radiate in only one direction so there could be his meaning. (...) Writing in which all kinds of writing mingled seemed, not immoral, but amoral, even to the masses. Played in every playground she found; no one can do that in a class or hierarchical society" (Acker, 1990). I don't want to insist on meaning. On my meaning. Or on my 'entitlement' to create meaning. Textual 'amorality' is a testing within and against a world that morally insists on and legally reinforces the figure of the authoritative and independent author and ignores that thought and text always only exist inside relations. 2

My eternal thanks to Jamie Allen for this. 
llegar a acuerdo con un tema; una resolución material, estética o ética (Barad, 1997) de la actividad relacional y multivocal de investigación, escritura y publicación, para permitir que otros se unan al diálogo. Para mí, escribir también es una herramienta para crear encuentros: con aquellos (humanos o no) que me rodean, me preceden o me sucederán; con la materialidad del pensamiento y el texto, la escritura y la publicación; con lo que siempre quedará fuera de la comunicación verbal. Encuentros también dentro y más allá de mi propia posición como una mujer europea, blanca, cis, hetero, de clase media, una académica feminista tendencialmente precaria que abandona y vuelve otra vez a la academia, y que intenta alinear de alguna manera sus proyectos editoriales experimentales transdisciplinarios (ejecutados principalmente en escuelas de arte y en el ámbito de la investigación basada en la práctica) con lo que requiere su posición como investigadora de doctorado en una universidad del Reino Unido y su práctica académica en general. Siempre me he sentido extrañamente desprovista de refugio aquí y allá, nunca ha sido mi objetivo ser parte de ninguno de los dos mundos. Sin embargo, con la esperanza (y el sentimiento) de formar parte: de los humanos o no humanos que me rodean, me preceden y me sucederán, cercanos e infinitamente separados, que perciben la publicación académica como una herramienta y un marco para cuestionar y confrontar sus mecanismos históricos, ideológicos y comerciales de inclusión y exclusión desde la perspectiva de la crítica feminista e interseccional de la producción de conocimiento.

$$
3
$$

En lugar de un generalizado hacer público, en este contexto publicar podría concebirse como la creación de un público (Warner, 2002), respectivamente como la instanciación perpetua de públicos diversificados en los diferentes momentos de la publicación en tanto proceso (antes y después del lanzamiento de una publicación) en torno a asuntos de preocupación específicos y comunes (Latour, 2005), sin negar ni ocultar su complejidad y ambigüedad y tomando en cuenta las múltiples comunidades involucradas en la producción de conocimientos (y también a aquellos que aún no se han involucrado).
PUBLICACIÓN I

(PREÁMBULO)

Las siguientes consideraciones se basan en un concepto amplio depublicación: publicar no es un «proceso Iineal a través del cual La escritura pasay está mediada por Los lectores» ( $\mathrm{Ma}$ Lik, 2008, p. 709), ni tampoco el momento en que se publica algo para una audiencia inespecifica ${ }^{3}$.

what will forever remain outside of verbal communication. Encounters as well within and beyond my own position as a European, white, cis, hetero, middle-class woman, a tendentially precarious feminist drop-out-and-back-again-academic, trying to somehow align what I worked on within transdisciplinary, experimental publishing projects (executed primarily within art school contexts and the realms of practice-based research) with what my position as a $\mathrm{PhD}$ researcher within a UK university and an academic practice in general require. I have always felt strangely shelterless here and there, never really aiming to be part of either world. Yet hoping (and feeling) to belong to the ones, human or not around me, before and after me, close and infinitely apart, that perceive academic publishing as a tool and framework to question and confront its historical, ideological, and commercial inclusions and exclusions from the perspectives of a feminist and intersectional critique of knowledge production.

PUBLISHING I

(PRELIMINARIES)

The following considerations are based on a broad concept of publishing: Publishing is neither a "Iinear process through which writing passes and is mediated to readers" (MaLik, 2008, p. 709) nor is it a single moment of releasing something to a not further specified public. Instead, it is an inherent 1 y relational interplay between a variety of processes and practices; Legal, cultural, economic, and political institutions; ecological, technological, and ideological underpinnings; tempora over lappings; fuman and non-human agencies. The relational activities publishing encompasses are found for example within research, reading, writing, and editing; referencing and 3

Rather than a generalized making public, publishing in this context could be described as the making of a public (Warner, 2002), respectively as the perpetual re-instantiation of diversified publics within different moments of publishing as process - before a publication's release and afterwards - around specific and common matters of concern (Latour, 2005), without negating or concealing their complexity and ambiguity, and accounting for the manifold communities involved in the production of knowledges (and for those who haven't been involved yet). 
Lapublicación es una interacción inferentemente relacional entre una variedad de procesos y prácticas; instituciones legales, culturales, económicas y politicas; fundamentos ecológicos, tecnológicos e ideológicos; superposiciones temporales; agencias humanas y no humanas. Las actividades relacionales que abarca La publicación se encuentran, por ejemplo, en La investigación, La Lectura, La escritura y la edición; Las referenciasy las anotaciones; y La creación, producción, circulación y recepción de conocimientos a través de las publicaciones (Malik, 2008; Thoburn, 2016). Debido a los nuevos modos de colaboración para reuniry compartir contenido (en plataformas como Google Docs y redes sociales), Los fimites entre estas actividades se han desdibujado, de modo que se han acercado tanto temporal como formalmente (Adema \& Marczewska, 2019).

Todo el alcance de este conjunto entre Lazado de actividades, agencias e instituciones debe ser abordado dentro y a través de una forma de publicar que, en Lugar de ser un simple gesto de representación, busque convertirse en una actividad politica e intervencionista y en una ferramienta potencialmente transformadora, que tenga la capacidad de despojarse de su propia cualidad de herramienta al servicio de una economía global del conocimiento y se convierta en un medio para perturbar e intervenir en los sistemas institucionales y neoliberales de producción y comunicación del conocimiento.

\section{PUBLICACIÓN ACADÉMICA}

A lo largo de su historia, la publicación académica ha estado estrechamente relacionada con la universidad como constructo ideológico y político, y como un sitio para producir conocimiento. Los sistemas de comunicación académica (de los cuales publicar forma parte), así como la propia academia, han sido fundamentales para definir qué es el conocimiento válido, cómo se siente y cómo se ve, de dónde y de quién proviene, $y$, en consecuencia, para determinar qué cuenta como trabajo académico y quién cuenta como académico. Estos sistemas se encuentran intrincados con la producción de conocimiento académico, la consolidación y representación de las disciplinas académicas, las comunidades y las motivaciones (Latour \& Woolgar, 1986; Malik, 2008; Windgätter, 2016). Además —si- annotating; the creation, production, circulation and reception of knowledges through publications (Malik, 2008; Tho6um, 2016). Due to new collaborative modes of assembling and sharing content (on platforms like Google Docs and social media) the boundaries between these activities have blurred, they have moved closer together, both temporally and formally (Adema \& Marczewska, 2019).

It is the full extent of this interwoven set of activities, agencies, and institutions that has to be attended to within and through a publishing that rather than a mere representational gesture, aims to be a political and interventionist activity and a potentially transformative toolbearing the capacity of transforming its own tooL-ness from something in service of a globalized know ledge economy into a means to unsett fe and intervene into institutional and neoliberal systems of know Ledge production and communication.

\section{ACADEMIC PUBLISHING}

Throughout its history, academic publishing has been closely entwined with the university as an ideological and political construct, and as a site for knowledge production. Systems of scholarly communication (of which publishing is a part), like academia itself, have been instrumental in defining what valid knowledge is, what it feels and looks like, where and from whom it comes, and-consequently-in determining what counts as scholarship and who counts as a scholar. They have been entangled with academic knowledge production, the solidification and representation of academic disciplines, communities, and motivations (Latour \& Woolgar, 1986; Malik, 2008; Windgätter, 2016). And - following the implicitly colonialist, patriarchal, and heteronormative ideals of Enlightenment humanism the modern university and its knowledge practices have been built upon - they have produced figurations of 'the other' (the one who does not produce useful knowledge or only 'non-knowledge'; the one who backs up and conveys knowledge in the 'right' way 
guiendo los ideales heteronormativos, colonialistas y patriarcales implícitos del humanismo ilustrado en los que se asientan la universidad moderna y sus prácticas de conocimiento-, han producido figuraciones del "otro" (aquel que no produce conocimiento útil o solo produce "no-saber"; aquel que respalda y transmite conocimiento de la manera "correcta" $y$ aquel que no, etc.) en función del género, el origen étnico y la geografía.

Estas declaraciones de valores implícitos se han entrelazado con la concepción moderna del ser humano como el sitio de la invención de la racionalidad o la razón instrumental, siguiendo una agenda predominantemente masculina (Ahmed, 2017; Craig et al., 2011), entendida como una agenda de supervivencia auto-contenida y progresiva de uno-contra-el-mundo a través del avance de los intereses individuales. Posteriormente, este imaginario se ha reactualizado en las diversas formas que ha tomado la universidad como idea e institución, desde la universidad de la cultura, orientada a la «producción de sujetos nacionales» (Readings, 1999, p. 46), hasta la universidad contemporánea neoliberal y empresarial de excelencia (Álvarez Solís, 2018). Esta última, un sistema globalizador, economicista y orientado a la eficiencia, vincula los valores colonialistas, patriarcales y heteronormativos con «una visión particular del mundo, con frecuencia un mundo neoliberal de Estados que compiten e individuos emprendedores susceptibles a los rankings y los intercambios comerciales de suma cero» (Shorish \& Chan, 2019, párr. 4). En este contexto, la existencia de instrumentos de evaluación, medición y validación cada vez más unificados fomenta la segregación — no solo ideológica, sino también económica-y conduce a la exclusión de aquellos que no están dispuestos a competir, o simplemente no son (económicamente) capaces de hacerlo, dentro de la agenda de este sistema depredador. Por ejemplo, instituciones y campos de investigación mal financiados; académicos que hacen correctamente su trabajo en contextos locales y regionales y son sensibles a las necesidades específicas en lugar de tratar de impactar el conocimiento mundial (Gray et and the one who does not, etc.) based on gender, ethnicity, and geography.

These implied value statements have been interlaced with the modern conception of the human (body) as the site of the invention of rationality or instrumental reason, following a predominantly male (Ahmed, 2017; Craig et al., 2011) agenda, understood as a self-contained and progressive one-against-all-survival through the advancement of individual interests. This imagery has been subsequently re-actualized in the diverse forms the university as an idea and an institution has taken - from the university of culture, aimed at the "production of national subjects" (Readings, 1999, p. 46), to the contemporary neoliberal and managerial (Álvarez Solis, 2018) university of excellence. The latter, an efficiency driven, economizing, and globalizing system, ties in colonialist, patriarchal, and heteronormative values with "a particular view of the world - most frequently a neoliberal world of competitive states and entrepreneurial individuals amenable to rankings and zero-sum market exchanges" (Shorish \& Chan, 2019, para. 4). Against this background, increasingly unified assessment, measuring, and validating instruments further an ideological but also economical segregation and lead to the exclusion of those who are not willing nor (financially) able to compete along with the agenda of this predatory system e.g. poorly funded research fields and institutions; academics who are practicing their scholarship positively within local and regional contexts and are responsive to corresponding needs rather than seeking to impact world-class knowledge (Gray et al., 2012, Méndez Cota, 2018); initiatives and individuals pursuing critical, queer, experimental, and collective approaches to research, writing and circulating knowledge(s) that are (due for example to content, argumentative form, open-endedness, presentability, or pace) not considered valuable within the calculative and individualizing logics of the contemporary knowledge economy (Shorish \& Chan, 2019). 
al., 2012; Méndez Cota, 2018); iniciativas e individuos que desarrollan enfoques críticos, queer, experimentales y colectivos para la investigación, la escritura y la circulación de conocimientos que, por diversos motivos (por ejemplo, debido al contenido, la forma argumentativa, la indefinición, la presentación o el ritmo), no se consideran valiosos dentro de las lógicas individualizadoras y calculadoras de la economía contemporánea del conocimiento (Shorish \& Chan, 2019). Estos mecanismos se reflejan en el modelo centro/ periferia de la geopolítica del conocimiento, en el que solo hay unas pocas naciones (como el Reino Unido, Estados Unidos, Francia e Italia) al centro de las redes mundiales de información, «que están exportando $y$, en efecto, "universalizando" su conocimiento (...) y una gran cantidad de otras naciones fuera del centro que (...) no tienen oportunidades de publicar, exportar o siquiera desarrollar su propio conocimiento “universal”» (Hall, 2019, párr. 11).

En este contexto, los ideales ilustrados de individualización, desapego y unidad entre el autor y el trabajo que se encuentran alojados en las prácticas y motivaciones de la publicación académica —las cuales determinan, por ejemplo, la figura del autor-propietario en el modelo de derechos de autor (Adema, 2019, p. 74)-, se han entrelazado cada vez más con los imperativos y las ansiedades (¡publicar o morir!) producidos por el mercado del conocimiento, respecto, por ejemplo, a la precariedad del empleo (y la competencia por él), así como en relación a las prácticas comerciales de una industria editorial mercantil (Moore, 2019a). Efectivamente, hoy la existencia de un tipo de publicación impulsada por el mercado empuja a los académicos a publicar de maneras que benefician a sus carreras «dentro de la estructura de una academia globalizada que únicamente incentiva las publicaciones en revistas de "primer nivel", avaladas por sus factores de impacto y la marca de quien las publica» (Shorish \& Chan, 2019, párr. 5). Cada vez más, las editoriales universitarias se ven obligadas a adaptar sus políticas a las estrategias de las editoriales multinacionales con fines de lucro (Moore, 2019a, $2019 \mathrm{~b}$ ), las que controlan una gran parte del mer-
These mechanisms are reflected in the center/ periphery model of the geopolitics of knowledge, in which there are just a few nations (such as the UK, Us, France, and Italy) at the center of the global information networks, "who are exporting, and in effect 'universalizing', their knowledge (...) and a whole host of other nations outside of the centre who (...) don't have opportunities to publish, export, or even develop their own 'universal' knowledge" (Hall, 2019, para. 11).

In this context, the Enlightenment ideals of individuation, detachment, and unity of author and work embedded in scholarly publishing practices and motivations, determining for example the figure of the author-owner in the copyright model (Adema, 2019, p. 74), have been increasingly interlaced with the imperatives and anxieties (publish or perish!) produced by the knowledge market regarding, for example, the precariousness of (and competition for) employment, and the business practices of the commercial publishing industry (Moore, 2019a). Today market-driven versions of publishing push academics to publish in ways that benefit their careers "within the structure of a globalized academy that solely incentivizes publications in 'top-tier' journals signified by their impact factors and publisher's brand" (Shorish \& Chan, 2019, para. 5). University presses are increasingly forced to adapt their policies to the strategies of the multinational for-profit publishing houses (Moore, 2019a, 2019b), who control a large section of the market: companies like Reed-Elsevier, Taylor \& Francis, Wiley-Blackwell, Springer, and Sage consolidated journal content through horizontal integration - in 2013 they accounted for more than $50 \%$ of all papers published across disciplines (Larivière et al., 2015). Lately they have been integrating "once disparate journal production workflows, research tools, data services, and researcher profiles" (Shorish \& Chan, 2019, para. 3) within end-to-end platforms such as the research information management system Pure. 
cado: empresas como Reed-Elsevier, Taylor \& Francis, Wiley-Blackwell, Springer y Sage consolidaron el contenido de las publicaciones académicas a través de la integración horizontal: en 2013, representaban más del 50 por ciento de todos los artículos publicados en todas las disciplinas (Larivière et al., 2015). Últimamente, estas multinacionales han estado integrando «flujos de trabajo de producción de revistas, herramientas de investigación, servicios de datos y perfiles de investigadores que alguna vez fueron dispares» (Shorish \& Chan, 2019, párr. 3) dentro de plataformas de extremo a extremo como Pure, el sistema de gestión de información para investigaciones. $\mathrm{Su}$ objetivo de «extraer grandes cantidades de datos que les permitan desarrollar nuevos productos y servicios para el mercado global de métricas, análisis y rankings de universidades» (Shorish \& Chan, 2019, párr. 3) se expresa, por ejemplo, en el documento de negociación entre las universidades holandesas y Elsevier que se filtró a principios de noviembre de 2019, el que recientemente ha estado circulando en Twitter. A cambio de conceder acceso abierto total, Elsevier solicita la plena cooperación en varios de sus proyectos de (meta)datos (Knecht, 2019).

Podemos rastrear el efecto extractivo, instrumentalizador y ordenante de la publicación en las prácticas académicas cotidianas, tal como Samuel Moore lo describe a partir de su perspectiva como académico en el campo de las humanidades:

Los proyectos se llevan a cabo con formatos de publicación específicos en mente; la elección de las revistas está determinada, con frecuencia, por cuán bien consideradas están por los paneles de evaluación; y existe una jerarquía informal acerca de ciertos tipos de publicaciones académicas, desde la monografía en lo más alto, hasta trabajos en coautoría y capítulos de libros en volúmenes editados en lo más bajo (Moore, 2019a, p. 41).

Muchos académicos critican activamente a las instituciones y las prácticas neoliberales de las economías del conocimiento, pero lo cierto es que a menudo se dejan llevar por la presión por publicar en

Their aim "of extracting vast quantities of data that would allow them to develop new products and services for the global marketplace of metrics, analytics, and university ranking" (Shorish \& Chan, 2019, para. 3) is expressed for example in a negotiation document between Dutch Universities and Elsevier that was leaked in early November 2019 and has been recently circulating on Twitter. In exchange for full open access, Elsevier requests full cooperation in a number of their (meta)data projects (Knecht, 2019).

The extractive, instrumentalizing, and ordering effect of publishing can be traced down to everyday academic practices, as Samuel Moore describes from his perspective of a humanities scholar:

Projects are undertaken with specific publication formats in mind; journal choice is frequently determined by how well regarded they are by assessment panels; and there is an informal hierarchy of certain kinds of academic publication, from the monograph at the top down to co-authored works and book chapters in edited volumes towards the bottom. (Moore, 2019a, p. 41)

Many scholars actively criticize the neoliberal institutions and practices of knowledge economies, but often the pressure to publish in a traditional, often commercial, manner takes the upper hand. 4

PUBLISHING II

( $T O$ THE HORIZON... AND BEYOND?)

Publishing, or rather the horizon of the publishable, precedes and constitutes bot $\mathrm{h}$ what can be written and read. (...) [The] horizons of the publishable (...)

4

This would include: books on sustainability printed on chlorine bleached and kaolin coated paper; books on unpaid work based entirely on free labor and self-exploitation; books by scholars "working in post-colonial studies to publish their monograph (...) with a university or commercial academic press that outsources its production labors (copy-editing, typesetting, coding, printing, e-book conversion, data management, etc.) to private companies such as Newgen Knowledge Works, Ltd., based in Chennai, India (...) which has zero transparency relative to the working conditions of its employees (but you can bet they are not the best, given how cheap their services are)" (Joy, 2017, para. 11). 
las formas más tradicionales y generalmente en editoriales comerciales ${ }^{4}$.

PUBLICACIÓN II

(HASTA EL HORIZONTE... ¿Y MÁS ALLÁ?)

La publicación, o más bien, el horizonte de lo publicable, precede y constituye tanto lo que se puede escribir como lo que se puede leer. (...) [Los] horizontes de lo publicable (...) rigen lo que se puede publicar dentro de un momento fistórico particular (...) [eI] forizonte denota (...) un Límite o frontera (Malik, 2008, pp. 709, 721).

¿Cómo sería una publicación que opera dentro de los «horizontes de Lo publicable», pero que, adoptando una perspectiva feminista e interseccional, también se abre paso siempre más allá de esos horizontes para confrontar las desigualdades fistóricas a lojadasy continuamente perpetuadas a interior de Los sistemas de comunicación académica (de Los cuales La publicación es una parte)? En la tradición de las iniciativas editoriales contrahegemónicas que se han desarrollado en los siglos $\mathrm{xx}$ y xxI, pero también en el contexto especifico de La Lucha antihegemónica (Kiesewetter \& Kol6, 2019) promovida durante décadas por movimientos feministas, queer, antico Lonialistas y antirracistas, asi como por epistemo logías no eurocentristas que se posicionan en experiencias encarnadas de racialización, discriminacióny resistencia contra Las formas de dominación interseccional en La academia (Jong et al., 2017, pp. 227-228; Leyva et al., 2015; Simpson, 2011; L. T. Smith, 1999), La publicación debería utilizarse como una práctica intervencionistay especulativa, como una herramienta para desarmar, dentro $y$ a través de La publicación, "Lo que ya se ha ensamblado (...) [preguntando] a qué nos oponemos y qué es aquello que favorecemos» (A A hmed, 2017, p. 2). Si La publicación ha sido

4

Esto incluye, por ejemplo, libros sobre sostenibilidad impresos en papel blanqueado con cloro y recubierto de caolín; libros sobre el trabajo no remunerado completamente basados en trabajo gratuito y auto-explotación; libros escritos por académicos «que trabajan en estudios poscoloniales que publican su monografia (...) con una editorial académica universitaria o comercial que externaliza sus trabajos govern what is thinkable to publish within a particular fistorical moment (...) [the] forizon denotes (...) a boundary or limit. (Malik, 2008, pp. 709, 721)

Fow would a publishing be that operates within but - adopting a feminist and intersectiona perspective - also always works its way beyond the 'horizons of the publishable' in order to confront historic inequalities embedded and continuously perpetuated within systems of scholarly communication (of which publisfing is a part)? In the tradition of counterhegemonial publishing initiatives throughout the $20^{\text {th }}$ and $21^{\text {st }}$ centuries but specifically also against the background of decades of anti-hegemonial struggle (Kiesewetter \& KoIb, 2019) by feminist, queer, anticolonial, and anti-racist movements and non-Eurocentered epistemo Logies positioned in embodied experiences of racialization, discrimination, and resistance against intersectional forms of domination in academia (Jong et af., 2017, pp. 227-228; Leyva et af., 2015; Simpson, 2011; L. T. Smith, 1999), publishing would need to be used as an interventionist and speculative practice, as a tool to, within and through publishing, take apart "what has a fready been assembled (...) [asking] what it is we are against, what it is we are for" (Ahmed, 2017, p. 2). If publishing has been an inherentpart of doing scholarship (Adema, 2018; Marczewska, 2018), against tfis Gackground it also would be an undoing of scholarship (in so far as scholarship has remained complicit and perpetuates the mechanisms of exclusion based on class, gender, and racialbiases of enfightened humanism embedded in dominating scholarly knowledge practices, communication infrastructures, and systems), while exploring new and different publishing formats, practices, and institutions that allow one to imagine and perform more open, horizontal, and inclusive scholarly forms and relations of knowledge production (Adema, 2018). Would a publishing that is a 'doing scholarship' as weIf as an 'undoing scholarship', in its uftimate consequence, not impLy academic suicide - rather than publish according to the violent terms of the market-driven academia (its normalisation 
una parte in fierente del trabajo académico (Adema, 2018; Marczewska, 2018), en este contexto también sería una forma de deshacer[o, ya que el trabajo académico ha sido un permanente cómplice y perpetuador de los mecanismos de exclusión basados en sesgos de clase, raza y género que caracterizan al fumanismo ifustrado, los que han estado aLojados en Las prácticas dominantes del conocimiento académico, Las infraestructuras de comunicacióny los sistemas. Deshacer e trabajo académico permite exp Lorar nuevosy diferentes formatos de publicación, asi como nuevas prácticas e instituciones que permitan imaginar y performar modos académicos más abiertos, horizontales e inclusivos para las relaciones de producción de conocimiento (Adema, 2018).

Una forma de publicación que implique "hacer trabajo académico"y, a la vez, "deshacer el trabajo académico", ¿no implicaría finalmente un suicidio académico? En Lugar de publicar de acuerdo con los términos vio Lentos de La academia de mercado (La normalizada concepción del trabajo académico que se juzga relevante solo en la medida en que esté validado por Los instrumentos cada vez más unificados de evaluación, medición y validación de La economía del conocimiento), ¿simplemente... perecer?

\section{PUBLICACIÓN ACADÉMICA DE ACCESO ABIERTO}

La publicación de acceso abierto 5 se ha convertido, por ahora, en la corriente principal en la academia, lo que se refleja, por ejemplo, en las reformas nacionales de acceso abierto que se acometen en todo el mundo, así como en la estrategia Plan S, una iniciativa de la Comisión Europea que busca acelerar la transición a un acceso abierto pleno e inmediato. La mayoría de los académicos que se ocupan de la publicación de acceso abierto ubican las raíces de este movimiento en las primeras culturas gratuitas y de código abierto de Internet (Hall, 2008; Moore, 2019a, 2019b; Tkacz,

$$
5
$$

Un denominador común básico entre las múltiples formas en que se manifiesta la defensa del acceso abierto es la afirmación de que la investigación financiada con fondos públicos debe estar disponible para el público (es decir, se debe poder encontrar y leer) sin requerir pagos adicionales (por parte del público) (Willinsky, 2006). 2012; Willinsky, 2006), así como dentro del ámbito de las disciplinas científicas (Crawford, 2002; Hedlund et al., 2004). Sin embargo,

of scholarly work as relevant onLy in so far as it is validated by the increasingly unified assessment, measuring, and validating instruments of the knowledge economy)... just... perish?

\section{SCHOLARLY OPEN ACCESS (OA) PUBLISHING}

Open Access (OA) publishing 5 by now has become mainstream in academia, which is for example mirrored in national oA reforms worldwide and the Plan S Strategy: an initiative by the European Commission to accelerate the transition to full and immediate open access. Most of the scholars preoccupied with OA publishing locate the roots of this movement within the early Internet, free and open source cultures ( Hall, 2008; Moore, 2019a, 2019b; Tkacz, 2012; Willinsky, 2006), and within the realm of scientific disciplines (Crawford, 2002; Hedlund et al., 2004). However, many scholars also emphasize the importance of the humanities - specifically also of the cultural studies (Hall, 2008) - as the site where university traditionally thinks about itself, specifically for critical strands within the OA movement (Hall, 2008; Kember, 2014; Moore, 2019a). Samuel Moore, unlike many of his colleagues, highlights in this regard the crucial position that grassroots DIY publishers from the humanities and social sciences (Moore, 2019a) active in the '8os and early' 90 s also took - for example, digital repositories or journals launched on listservs and then the Web (e.g. Surfaces, from 1991, or Postmodern Culture, from 1990). The early scholar-led initiatives Moore mentions didn't aim to challenge only the commercial academic publishing industry through discursive or confrontational means, but also were constructing "alternatives to the kinds of organization that they resist" (Moore, 2019a, p. 133). They recognized the

$$
5
$$

A basic common denominator between the manifold forms in which OA advocacy is manifested, is the claim that publicly funded research has to be made available (findable and readable) to the public without requiring additional payments (from the public) (Willinsky, 2006). context of the emerging digitization and the new popularity of personal computing and networked technologies as a frame to address 
dado que son el ámbito en que la universidad suele pensarse a sí misma, muchos académicos también enfatizan la importancia de las humanidades - y específicamente de los estudios culturales (Hall, 2008)en relación a los asuntos críticos del movimiento por el acceso abierto (Hall, 2008; Kember, 2014; Moore, 2019a). Samuel Moore (2019a), a diferencia de muchos de sus colegas, destaca el rol crucial que jugaron los editores de las humanidades y las ciencias sociales anclados en la corriente activista DIY que se encontraban activos durante los ochenta y los noventa, y recurrían, por ejemplo, a repositorios digitales o lanzamientos a través de listas de distribución por correo electrónico y posteriormente a la Web (como es el caso de Surfaces, de 1991, o Postmodern Culture, de 1990). Estas primeras iniciativas dirigidas por académicos que menciona Moore no tenían como objetivo solo desafiar a la industria editorial académica mercantilista a través de discursos o confrontaciones, sino que también estaban ofreciendo «alternativas a los tipos de organizaciones a las que resistían» (Moore, 2019a, p. 133). Ellos reconocían que la digitalización emergente y la creciente popularidad de la informática personal y las tecnologías en red ofrecían un marco para abordar las importantes cuestiones éticas y políticas que se estaban planteando con respecto a la autoridad y legitimidad académica e institucional (Hall, 2008), proporcionando marcos críticos para una idea que, en sí misma, nunca ha sido intrínsecamente crítica (Adema, 2019; Bell, 2019; Hall, 2008; Moore, 2019b).

En este contexto, la crítica del trabajo académico posmoderno expresada en el primer número de Postmodern Culture (PMC) por Bell Hooks y sus contemporáneos (y expertos como Moore) podría haberse interpretado como una declaración académica de intenciones (expresadas por una mujer negra) encaminadas a lograr la apertura de la universidad moderna y superar sus ideales implícitamente colonialistas, patriarcales y heteronormativos:

Es tristemente irónico que el discurso contemporáneo que más habla sobre la heterogeneidad y el su- important ethical and political questions that were being raised concerning academic and institutional authority and legitimacy (Hall, 2008), providing critical framings for an idea that in itself never has been intrinsically critical (Adema, 2019; Bell, 2019; Hall, 2008; Moore, 2019b).

Against this background, the critique of postmodernist scholarship voiced in the first issue of Postmodern Culture (PMC) by Bell Hooks and her contemporaries (and experts like Moore) might have been read as a scholarly declaration of intent (voiced by a black woman) towards an opening out from the modern university and its implicitly colonialist, patriarchal, and heteronormative ideals:
It is sadly ironic that the contemporary discourse which talks the most about heterogeneity, the decentered subject, declaring breakthroughs that allow recognition of otherness, still directs its critical voice primarily to a specialized audience, one that shares a common language rooted in the very master narratives it claims to challenge. If radical postmodernist thinking is to have a transformative impact, then a critical break with the notion of 'authority' as 'mastery over' must not simply be a rhetorical device, it must be reflected in habits of being, including styles of writing as well as chosen subject matter. (Hooks, 1990, para. 6)

In retrospect, however, Hook's claim, rather than a promise, reads like a self-fulfilling prophecy, specifically in these cases in which funding and policy driven $\mathrm{OA}$ publishing has been regarded as a business model in line with the agendas of the neoliberal knowledge economy "retaining and further exploiting existing relations [within the logics of the centre/periphery model of the geopolitics of knowledge] instead of disrupting them" (Adema, 2018 , p. 19), and parasitizing open forms of communication "by mining and selling the data around our content" (Adema, 2018, p. 19). This happens for example within the context of multinational companies such as the already mentioned Reed-El- 
jeto descentrado, declarando avances que permiten el reconocimiento de la otredad, todavía oriente su voz crítica principalmente a una audiencia especializada, una que comparte un lenguaje arraigado en el dominio de las mismas narrativas que dice desafiar. Si el pensamiento posmodernista radical ha de tener un impacto transformador, entonces una ruptura crítica con la noción de "autoridad" entendida como "dominio sobre" no debe ser simplemente un dispositivo retórico, sino que debe reflejarse en los hábitos de ser, incluidos los estilos de escritura y los temas elegidos (Hooks, 1990, párr. 6).

En retrospectiva, sin embargo, en lugar de ser una promesa, la crítica de Hook se lee como una profecía autocumplida, específicamente en los casos en que el financiamiento y las políticas orientadas al acceso abierto han sido consideradas como un modelo de negocio alineado con las agendas de la economía neoliberal del conocimiento, orientado a «retener y explotar aún más las relaciones existentes [dentro de las lógicas del modelo centro/periferia de la geopolítica del conocimiento] en lugar de interrumpirlas» (Adema, 2018, p. 19) y parasitando las formas abiertas de comunicación «al minar y vender los datos asociados a nuestro contenido» (Adema, 2018, p. 19). Esto sucede, por ejemplo, en el contexto de empresas multinacionales como las ya mencionadas Reed-Elsevier, Taylor \& Francis, Wiley-Blackwell, Springer y Sage, que utilizan plataformas end-to-end de acceso abierto para extraer datos (como el sistema de gestión de información para investigaciones Pure).

\section{PUBLICACIÓN III}

(APERTURA I)

En el contexto de Las diversas concepciones comerciales de La publicación de acceso abierto, asi como también en el activismo pionero y contemporáneo del código abierto, aparece como una figura retórica persistente y notoria La simplificacióny genera lización de La apertura como portadora de "beneficio socialy politico en todos Los casos» (Christen, 2012, p. 2878). La idea de una apertura totalo generalizada en el contexto de la digitalización se basa en sevier, Taylor \& Francis, Wiley-Blackwell, Springer, and Sage that use OA end-to-end platforms such as the research information management system Pure to extract data.

PUBLISHING III

(OPENNESS I)

Within the context of commercial conceptions of $O A$ publishing, but also within the claims of early and contemporary open source advocacy, a notorious simplification and generalisation of openness as a carrier of "social and political benefit in all cases" (Christen, 2012,p. 2878), has Geen a persistent rhetorical figure. The idea of a total or generalized openness in the context of digitization is based on the assumption that "information wants [and has] to be free" (Christen, 2012, p. 2870), and is 'free' once it has been shared via digitalp latforms and repositories. This simplified notion overshadows for example the uneven distribution of access to technology and the necessary skills to produce and to access information, replicating gender inequalities, as well as class and race divisions, both within early Internet cultures and within a globalperspective today. It also ignores that definitions of openness, for example in the case of vufnerable indigenous, cultures, and knowledges (Povinelli, 2011), are specific and context-related. The supposition of a 'total openness' furthermore fails to name enclosure as a fundamentalpart of openness. In consequence, specifically if used in the context of an increasingly branding-focused, market and profitdriven academic knowledge industry, in which funding and policy driven $O A$ models pursue the idea of $O A$ as a business, it therefore overshadows the inequalities in the institutional legitimation of knowledges, in line with the implicitly colonialist, patriarchal, and heteronormative ideals of Enfightenment humanism that have been re-actualized within today's neoliberal university of excellence. 
elsupuesto de que «La información quiere [y tiene que] ser Libre» (Christen, 2012, p. 2870), y es "il6re" una vez que se ha compartido a través de plataformas digitales y repositorios. Esta noción simplificada eclipsa, por ejemplo, La distribución desigual del acceso a la tecnoLogía y las habilidades necesarias para producir y acceder a información, replicando Las desigualdades de género, así como las divisiones de clase y raza, tanto en el contexto de las primeras culturas de Internet como desde la perspectiva global actual. También ignora que, en el caso de los ámbitos uufnerables, ya sean conocimientos, cufturas o grupos originarios (Povinelli, 2011), Las definiciones de apertura son especificas y están relaciona das con el contexto. Además, La suposición de una "apertura tota [" fracasa por su incapacidad de reconocer La clausura como parte fundamental de la apertura. En consecuencia, y especificamente si se usa en el contexto de una industria académica del conocimiento cada vez más centrada en La marca, Los mercados y el Lucro, en La cual Los modelos de financiamiento y las politicas de acceso abierto persiguen La idea de acceso abierto como una forma de hacer negocios, La idea de apertura total arroja sombras sobre las desigualdades en la legitimación institucional de Los conocimientos, en finea con los ideales implicitamente colonialistas, patriarcales y heteronormativos del humanismo ifustrado, Los cuales se han reactualizado en Ia universidad neoliberal de excelencia.

\section{PUBLICACIÓN IV}

(APERTURA II)

En Lugar de sentir La tentación de rendirse respecto de la narrativa de La apertura total, Las iniciativas editoriales especificamente interseccionales y feministas de hoy exigen re-politizar La aperturay hacer La más compleja (Kember, 2014), asi como las relaciones e identidades de Las que emerge y sus instanciaciones (Shukaitis, 2014). Estas iniciativas conciben La apertura como performativa, inherentemente relacional, posicionada y autorreflexiva; como algo que no es preexistente, sino que se debe establecer perpetuamente en Los encuentros, cuy as formasy modalidades no se especifican fuera de La relación (BerLant, 2016; Kiesewetter \& Ko (6, 2019). La "apertura para", pasiva y generalizada, es reemplazada por La "apertura con", activa y procesual, en ana logía con La práctica de "escribir con" o

\section{PUBLISHING IV}

(OPENNESS II)

Instead of being tempted to give in with the narrative of tota lopenness, specifically intersectional and feminist publishing undertakings today call for a complication and re-politicization of openness (Kember, 2014) and the relationships andidentities it is emerging from and instantiating (Shukaitis, 2014). They recognize openness as performative, inferently relational, positioned, and self-reflexive; as something that is not pre-existing but has to be established perpetually within encounters, whose forms and modalities are not specified outside of relation (BerLant, 2016; Kiesewetter \& KoIb, 2019). The passive and generalized 'open for' is replaced with an active and processual'opening with', in an ana logy to a practice of 'writing with', or 'togethering' (Iyer Siddiqi, 2018). It is, instead of assimilating difference or instrumentalizing it in forms of othering, acknow Ledging difference in situated and relational processes of 'opening out from...' (Kember, 2014) within the activities and processes of research, writing, and communicating - that are by necessity Loaded with potentially irresolvable frictions.

PUBLISHING V

(ONE PUBLISHES TO FIND COMRADES)

'One publishes to find comrades' - the words the surrealist André Breton allegedly uttered in 1920 might be the most used to describe the social and relational character of publishing and publications. Publishing bears the potential to methodo logically bring together different agencies, experiences, knowledge practices, and

6

"To me, this would mean privileging the labor constituted in the process of writing with colleagues, however varied the tasks each performs or disparate the connection each might retain to the written result. It would mean valuing the engaged thinking and mutual care for those in the collaboration as highly, even more highly, than the published product. It would mean redefining writing as a long and rigorously nonviolent process of thought and care." (lyer Siddiqi, 2018, sec. 3) systems around collective issues or topics. These encounters are given a rhythm through the processes and activities pertaining to publishing. This relational and community forming potential of publishing 
"hacer en conjunto"' (Iyer Siddiqi, 2018). Se trata, en Lugar de asimiLar La diferencia o instrumentalizarla en formas de alteridad, de reconocer la diferencia de Los procesos situados y relacionales de "apertura desde..." (Kember, 2014), al interior de las actividades y los procesos de investigación, escritura y comunicación, que necesariamente están cargados de fricciones potencialmente irresolubles.

\section{PUBLICACIÓN V}

(UNO PUBLICA PARA ENCONTRAR CAMARADAS)

\section{"Uno publica para encontrar camaradas": Las palabras} supuestamente pronunciadas por el surrea lista André Breton en 1920 podrían ser las más utilizadas para describir el carácter socialy relacional de Las publicaciones. La publicación tiene elpotencial de reunir metodológicamente diferentes agencias, experiencias, prácticas de conocimiento $y$ sistemas en torno a problemas o asuntos colectivos. Estos encuentros se producen rítmicamente a través de Los procesos y Las actividades relacionadas con La publicación. Este potencial relacionaly de formación de comunidades que tienen Las publicaciones va más allá de La difusión común del conocimiento. Puede desplegarse también a nivel estratégico a través de la posibilidad de abrirse a - e imponer-ciertos modos y valores dentro de la relación (en La organización, el actuary el trabajo conjunto) y rechazar otros (a través de la distancia geográfica y más allá de La similitud o La supuesta equidad como base para una participación común).

¿Quépasaría si, en este contexto, el carácter relacional de La publicación estuviera puesto radicalmente en primer plano y La publicación (Las actividades de investigación, escritura y comunicación) fuese concebida como una práctica para "abrirse con", como una actividad relacional de "hacer en conjunto", renegociando perpetuamente a quiény a qué se abre uno y con quién se invo Lucra

«Para mí, esto significaría privilegiar el trabajo constituido en el proceso de escritura con colegas, independientemente de cuán diferentes sean las tareas que cada uno realiza o cuán dispar sea la conexión que cada uno tiene con el resultado escrito. Significaría valorar muchísimo el pensamiento conjunto y el cuidado mutuo de quienes participan, incluso más que el producto publicado. Significaría redefinir la escritura como un proceso, largo y rigurosamente no violento, de pensamiento y cuidado» (Iyer Siddiqi, 2018, sec. 3). a La hora de investigar, escribiry comunicar, y también a quién y a qué uno no se abre, para crear nuevos encuentros -esta vez diferentes, frágiles, aterrizados, reflexivos y autocríticoscon Lapublicación and publications exceeds the common dissemination of know ledge. It can unfold also on a strategical level through the possibility of opening out towards and enforcing certain modes and values within relation (within organizing, acting, and working together) and refusing others - across geographical distance and beyond similarity or presupposed equity as a base for common engagement.

What if, against this background, the relational character of publishing were radically foregrounded, and publishing - the activities of research, writing, and communicating - was understood as a practice of 'opening with', as a relational activity of 'togethering', perpetualfy renegotiating who and what one opens out to and become involved with when researching, writing, and communicating, and to whom and what not, making new and different fragife, grounded, reflexive, self-critical encounters - with and within publishing as a concept, an institution, and a social process? With publishing's past(s), present(s), and future(s)? With publisfing traditions in and outside of academia? With artistic, feminist, and intersectional activism and activists beyond academia and across time? With different and divergent knowledges, and what has been considered non-knowLedge before? With the human and non-human agencies involved in publishing and with the ones that are not (yet)? How would these encounters be like, feel like, evolve like?

\section{PUBLISHING VI}

\section{(A THOUGHT EXPERIMENT)}

Publishing like this, a doing scholarship that is also always an undoing scholarship, demands to reassess "what threatens and what comforts, it changes the referent of dread and the refuge" (Ber Lant, 2016, $p$. 411). It means to reconsider the own positioning within and beyond an academic system that - while providing Less and less space for critica lengagement - stilf offers a certain degree of stabifity and security (at least one has ajo6!).

Apart from the undoubtedly increasingly Gizarre terms on which the commercial strands of $O A$ publishing operate within the know ledge economy 
(y en ella) como concepto, institución y proceso social? Encuentros con Los pasados, Los presentes y los futuros de Las publicaciones... Con Las tradiciones editoriales dentroy fuera de la academia... Con el activismo artístico, feminista e intersecciona Iy con Los activistas que se desenvuelven más allá de La academia y a través del tiempo... Con conocimientos diferentes y divergentes, con lo que antes se consideraba un "no-saber"... Con Las agencias humanasy no fumanas involucradas en la publicacióny con las que no lo están (aún)... ¿Cómo serían, se sentirían y evoLucionarian estos encuentros?

\section{PUBLICACIÓN VI}

(UN EXPERIMENTO DEL PENSAMIENTO)

Una forma de publicar como esta, una forma de hacer el trabajo académico y también de deshacer[o, exige reevaluar "Lo que amenaza y lo que conforta, cambiar el referente del temory el refugio» (Ber Lant, 2016, p. 411). Implica también reconsiderar el propio posicionamiento en el sistema aca démico y más allá de él, un sistema que, si bien ofrece cada vez menos espacio para el compromiso crítico, aún ofrece un cierto grado de estabilidady seguridad (jalmenos nos permite trabajar!).

Más allá de los términos indudablemente cada vez más extraños en los que operan los aspectos comerciales de La publicación de acceso abierto en La economía del conocimiento, ¿puedes «ver Lo "extraño" también en nuestras posiciones más "serias"》 (Stengers \& Bordeleau, 2011, p. 12) relacionadas con Las publicaciones?

Ya que «el inconveniente gesto de una ana Logía incómoda es el materia Lprincipa L para La deliteraLización del mundo» (Ber Lant, 2016, p. 414), ¿qué "analogías incómodas" puedes encontrar para las estrategias y exclusiones sobre las cuales reivindicany ganan su autoridad las publicaciones; para Los formatos, plazos y estándares que sustentan los regímenes de La academia occidentaLy La economía neoliberal del conocimiento; para Los marcos de pensamiento que han producido las formas en que el conocimiento es creado, mediado y recibido; $y$ para tus propias verdades y certezas: ef propio "nosotros" de La "pertenencia representaciona Г"?

Flay un impetu performativo en el hecho de revocar continua y gradua Imente el apoyo activo de la predilección por Los "prestigiosos" sistemas eurocéntricos
- can you "see the 'bizarre' also in our most 'serious' holdings" (Stengers \& Bordeleau, 2011, p. 12) related to publishing?

By reason that "the inconvenient gesture of awkward analogy is prime material for deliteralizing the wor [d" (BerLant, 2016, p. 414), what "awkward analogies' can you find for the strategies and excLusions on which publications claim and gain authority; for the formats, time frames, and standards that sustain the regimes of Western academia and the neoliberal knowledge economy; for the frames of thought, which have produced the ways knowledge is created, mediated, and received; and for your own trut ths and securities, the own 'we'-s of 'representational belonging'?

There is a performative impetus in continuously and gradually revoking the active support of the preference of "prestigious' Euro-centric research [and communication] systems that continue to undermine other epistemic communities from around the wor [d" (Shorish \& Chan, 2019, para. 9).

\section{CARING PRESSES}

Certain strands within the $\mathrm{OA}$ movement recognize the problems resulting from an increasingly branding-focused, market and profit-driven academic publishing industry coming along with a decline in State funding for higher education in many countries. They oppose for example disproportionally inflated journal subscription fees and excessive article and book processing charges, some funders' policies that request publication in (often expensive) high-profile journals, and those financing models that propose to shift the accruing costs from the public towards the authors and libraries (Arbuckle \& Maxwell, 2019). Specifically not-for-profit scholar-led presses (such as Mattering Press, Minor Compositions, Punctum Books, and Open Humanities Press) that are organized within networks like the Radical Open Access Collective, have countered the developments driven by commercial academic publishing and business oriented OA models - e.g. the existing legacy model of publishing, with its neoliberal focus 
de investigación [y comunicación] que continúan menoscabando a otras comunidades epistémicas de todo el mundo» (Shorish \& Chan, 2019, párr. 9).

\section{EDITORIALES QUE CUIDAN}

Ciertos sectores del movimiento por el acceso abierto reconocen los problemas que suscita una industria editorial académica cada vez más centrada en la marca, orientada al mercado y el lucro, que además coincide con la disminución de los fondos estatales para la educación superior en muchos países. Se oponen, por ejemplo, a las tarifas de suscripción desproporcionadamente infladas de algunas revistas y los onerosos costos asociados al procesamiento de artículos y libros, a algunas políticas de financiamiento que solicitan expresamente la publicación en revistas de alto perfil (a menudo costosas) y a aquellos modelos de financiamiento que proponen transferir los crecientes costos que hoy paga el público hacia los autores y las bibliotecas (Arbuckle y Maxwell, 2019). Concretamente, editoriales sin fines de lucro dirigidas por académicos (como Mattering Press, Minor Compositions, Punctum Books y Open Humanities Press) que se organizan en torno a redes como el Radical Open Access Collective, han contrarrestado conceptual, formal y organizativamente los procesos impulsados por la publicación académica comercial y los modelos de publicación abierta orientados a los negocios (por ejemplo, la tradición del actual modelo de publicación neoliberal enfocado en marcas individuales de autor y productos cuantificables, así como los efectos globales de las economías neoliberales del conocimiento). Asimismo, han estado insistiendo en el potencial de la publicación de acceso abierto como una «oportunidad para romper con los cimientos colonialistas de nuestra infraestructura de comunicación académica y rehacer nuestros sistemas para que constituyan representaciones más precisas del conocimiento colectivo de la humanidad» (Shorish \& Chan, 2019, párr. 10). Y preguntan, con Gabriela Méndez Cota:

¿Qué es ese trabajo académico en el que se espera que uno participe, al cual se espera que uno se igua- on individual authorial brands and measurable quantifiable outputs, and the global effects of neoliberal knowledge economies - conceptionally, formally, and organizationally. They also have been insisting on the potential of OA publishing as an "opportunity to break from the colonialist foundations of our scholarly communication infrastructure and remake our systems to be more accurate representations of humanity's collective knowledge" (Shorish \& Chan, 2019, para. 10). And they ask, with Gabriela Méndez Cota:

What is that scholarship one is expected to participate in, to be equal with, under what conditions, with what consequences, and for whom exactly? Is scholarship the same thing and equally relevant to everyone in the world, so that participation in it is mostly a matter of economic access, technical expertise or academic know-how? Is the will to participate about getting recognition ('being heard' or 'being seen') in the liberal terms universal scholarship or can it be, or even should it be, about attempting to transform the very definition and practice of scholarship in relation to particular situations? (2018, p. 16)

These editorials understand publishing as a complex, multi-agential practice, a political concern, and an instrument for enacting the world each press hopes to bring about (Adema \& Stone, 2017; Kember 2014; Moore, 2019a). Their publishing practices and agendas foreground collaboration (as opposed to competition), and they harness publishing's relational capacity. They are attending to the diverse forms of relationality that are being put into play within and through their publishing practice. The emphasis within publishing processes, agendas, and outcomes is shifted from a logic of rational, calculative individualism (and a focus on the 'author' and the 'outcome') towards a logic of community and care, and an ethics and practice of post-humanist 'mattering' (Adema, 2019; Haraway, 1988; 
le, bajo qué condiciones, con qué consecuencias y para quién exactamente? ¿Es el trabajo académico equivalente e igualmente relevante para todos en el mundo, y es la participación en él principalmente un tema de acceso económico, experiencia técnica o conocimiento académico? ¿La voluntad de participar tiene que ver con obtener reconocimiento ("ser escuchado" o "ser visto") en los términos liberales de universalizalización del trabajo académico o puede tener que ver, y más bien debe tener que ver, con un intento por transformar la definición y la práctica del trabajo académico en relación con situaciones particulares? (2018, p. 16).

Estas editoriales entienden que la publicación es una práctica compleja y multiagencial, un asunto político y un instrumento para enactar el mundo que cada una de ellas espera generar (Adema \& Stone, 2017; Kember 2014; Moore, 2019a). Sus prácticas y agendas editoriales ponen en primer plano la colaboración (en oposición a la competencia) y aprovechan la capacidad relacional de las publicaciones. Están abordando las diversas formas de relacionalidad que se ponen en juego en su práctica editorial y a través de ella. El énfasis en los procesos de publicación, las agendas y los resultados reemplaza la lógica del individualismo racional y calculador (y el enfoque en el "autor" y el "resultado") por una lógica de comunidad y cuidado, así como por una ética y una práctica poshumanista de reconocer las "materias que importan” (Adema, 2019; Haraway, 1988; Kember 2014), haciéndose responsable no solo por el conocimiento producido sino también por la forma en que este se produce (Adema, 2019; Kember 2014). Se trata de un «cuidado por los demás, por los procesos, por el trabajo involucrado en todos los aspectos de la cadena de suministros y por el contenido de la publicación» (Adema \& Moore, 2018, p. 8). Esta lógica del cuidado «se refiere, en parte, a visibilizar a los "otros invisibles", como los llama Joe Deville [uno de los editores de Mattering Press, la organización benéfica del Reino Unido]. Aquellos que representan la gran cantidad de trabajo que pasa desapercibido en este modelo
Kember 2014), taking on responsibility not just for the knowledge produced but also for the way in which it is produced (Adema, 2019; Kember 2014). Theirs is a "care for others, for processes, for the work involved in all aspects of the supply chain, and for the (content of the) publication" (Adema \& Moore, 2018, p. 8). This logic of care "refers, in part, to making visible the 'unseen others' as Joe Deville [one of the editors of UK registered charity Mattering Press] calls them. Those, who exemplify the plethora of hidden labor that goes unnoticed within this object and author-focused (academic) publishing model" (Adema, 2019, p. 77). It attends to the human but also the material relations instantiated within publishing processes: "various agencies involved in the production of scholarship, including 'authors, reviewers, editors, copy editors, proofreaders, typesetters, distributers, designers, web developers and readers' [McHardy, 2014]" (Adema, 2019, p. 76); as also production and reviewing models, the texts themselves, the formats and the channels through which these circulate, the work involved in making them circulate. By, for example, ensuring accountability and remuneration of work, as well as providing transparency on payment, production and reviewing models.

The engagement of these presses is driven by (feminist) ethics, perspectives and practices of 'making a difference' within the publishing process (in its totality seen as a process of producing knowledge differently). This ambition is attained by an attention to 'retaining differences' (lyer Siddiqi, 2018) and frictions - experimenting with and allowing for varying forms of collaboration and authorship, perspectives, and knowledge practices to exist, from the level of the page, to publication formats, to types of content, to publishing and oAs models, to the processes and organizational structures in which publishing evolves. As Eileen $A$. Joy, the director of Punctum Books, describes:

Academic Freedom is not a right to be granted to those with secure institutional status, but 
(académico) de publicación centrado en el autor y en el objeto» (Adema, 2019, p. 77). Aborda lo humano, pero también las relaciones materiales instanciadas dentro de los procesos de publicación: «varias agencias involucradas en la producción de trabajo académico, incluyendo "autores, pares evaluadores, editores, redactores, correctores, tipógrafos, distribuidores, diseñadores, desarrolladores web y lectores" [McHardy, 2014]» (Adema, 2019, p. 76); como también modelos de producción y revisión, los propios textos, los formatos y los canales a través de los cuales circulan, y el trabajo involucrado en hacerlos circular. Por ejemplo, se garantiza la transparencia en la rendición de cuentas y la remuneración del trabajo, así como en los modelos de pago, producción y revisión.

El compromiso de estas editoriales está impulsado por la ética, las perspectivas y las prácticas (feministas) que buscan "hacer una diferencia" en el proceso de publicación (visto en su totalidad como un proceso diferente de producción de conocimiento). Esta ambición se logra prestando atención a "conservar las diferencias" (Iyer Siddiqi, 2018) y las fricciones: experimentando y permitiendo que existan diversas formas de colaboración y autoría, así como diferentes perspectivas y prácticas de conocimiento, desde el nivel de la página hasta los formatos de las publicaciones, los tipos de contenido, los modelos de publicación y acceso abierto, y los procesos y estructuras organizativas en las que evoluciona la publicación. Tal como describe Eileen A. Joy, directora de Punctum Books,

La libertad académica no es un derecho que se otorgue a aquellos con un estatus institucional seguro, sino que es una lucha colectiva e interminable encaminada a limpiar y asegurar los espacios abiertos (y enriquecidos) que resultan tan necesarios para que la libertad se arraigue: para construir y fomentar espacios de hospitalidad radical en los cuales los investigadores individuales puedan tener más libertad para experimentar y arriesgarse de la que existe actualmente y, lo que es más importante, para buscar a través de sus trabajos sus propios deseos (y no rather is an endless, collective struggle to clear and secure the open (and enriched) spaces so necessary for freedom to take root - to build and foster spaces of radical hospitality within which individual researchers might have more freedom than currently exists to experiment, to take risks, and most importantly, to pursue in their work their (and not our) desires, unencumbered by professional anxieties over whether or not those desires are legitimated in advance by what particular fields have already deemed as 'proper' to themselves. (Joy, 2017, para. 12)

PUBLISHING VII

(ONGOING STRUGGLES)

Methodologically, instead of organizing, distributing, and institutionalizing responsibilities and agencies through top-down implemented rules and policies, the presses mentioned above involve in an active engagement with care not as a normative moralobligation, but as a "thick, impure, involvement in a wor Ld where the question of how to care needs to be posed [together, again and again]" (Puig de La Bellacasa, 2017, p. 6). Publishing as care is a movement that is never conclusive or contained, but on-going and futural, actual, and immediate, as the relationships that it produces are (Kember 2014, p. 113).

Under these premises, publisfing is manifesting itself as an instrument driving and guiding an ongoing struggfe situated in an agonistic $c^{7}$ (Mouffe, 2014) relationship with the system it challenges. It is an affirmative gesture of 'staying with the trouble' (Flaraway, 2016), within a nexus understood as the configuration of writing, reading, andpublishing its historical, ideological, and commercial inclusions and

7

Chantal Mouffe's concept of 'ago- However, would a process of 'opening nism' (2014), is referenced often by out from' not also imply the opening the strands of the $O A$ movement that out from this and other canonical point to the "important ethical and references? Not by getting rid of political questions that are being them or by replacing them, but by raised (...) concerning our relation- complicating them by opening out ship to knowledge and concerning from those whose critique (its figures academic and institutional authority of thought and action) is in line with, and legitimacy" (Hall, 2008, p. 12). authorized, and produced by 家 
los nuestros), libres de preocupaciones profesionales acerca de la necesidad de legitimar por adelantado esos deseos en función de aquello que los campos académicos han considerado "adecuado" para ellos mismos (Joy, 2017, párr. 12).

PUBLICACIÓN VII

(LUCHAS CONTINUAS)

Metodológicamente, en Lugar de organizar, distribuire institucionalizar las responsabilidades y las agencias a través de reglas y políticas implementadas de manera vertical, Las editoriales anteriormente mencionadas se involucran en un compromiso activo con el cuidado, no como una obligación moraL normativa, sino como una forma de «participación gruesa e impura en un mundo que debe plantearse la cuestión de cómo cuidar [juntos, una y otra vez]» (Puig de La Bellacasa, 2017, p. 6). Publicar atendiendo al cuidado constituye un movimiento que nunca es concluyente 0 contenido, sino continuo y futuro, actual e inmediato, taf como las relaciones que produce (Kember 2014, p. 113).

Bajo estas premisas, publicar se manifiesta a sí mismo como un instrumento que impulsa y guia una Lucha continua y situada en una relación agonista 7 (Mouffe, 2014) con el sistema que desafía. Es un gesto afirmativo de "quedarse con elproblema" (Jfaraway, 2016), en un nexo entendido como la configuración de escribir, Leer y publicar sus inclusiones y exclusiones fistóricas, ideológicas y comerciales, en Lugar de un elaborado plan de acción.

Publicar de este modo consume mucho tiempoy energía, es intrincado y complejo, está cargado de fricción y no es, de ninguna manera, constructivo (ni mucho menos recompensado) dentro del sistema de validación de una academia autoconteniday "progresista". Por el contrario, estas editoriales obtienen parte de su fuerza de la relación profundamente ambivalente con el sistema que desafian, asi como de la necesidad continua de reclamar y crear el espacio, el tiempo y los recursos necesarios para marcar La diferencia.

7

El concepto de "agonismo" de Chantal Mouffe (2014) es mencionado a menudo por los sectores del movimiento por el acceso abierto que apuntan a las «importantes cuestiones éticas y políticas que the practical, material, and ideological conditions of Western Enlightenment modernity, which they simultaneously have failed to interrogate. Opening out from the concept of agonism thus might mean thinking it together with Stefano Harney's and Fred Moten's 'appositionality' (2013), Saidiya Hartman's 'waywardness' (2019), Mia Charlene
White's 'blues epistemology' (2018) or Christina Sharpe's concept of 'wake work' (2016), as well as other theorists, whose radicality lies in the refusal of the very bases on which critique commonly is made available - bases created from an Enlightenment world view of oppositional thought (oppressed-oppressor, master-slave, just-unjust, etc.).

exclusions rather than an elaborate plan of action. A publishing like this is time and energy consuming, intricate, complicated, friztion Loaded, and by no means constructive (fet alone rewarded) within the validating system of self-contained, 'progressive' academia. To the contrary, these presses gain part of their drive from the deeply ambivalent relation to the system they chalfenge, the need to continuously claim and make the space, time, and resources required for making a difference.

PUBLISHING VIII

(COMMON BASES)

When committing to an opening out from academia towards the engagement of feminist and intersectional activism and activists across time and geography, the initiative Precarias a la deriva (Precarious women adrift) - situated between research and activism and the communication (publication) thereof - comes to mind: This group was active in and around'Madrid from 2002 onwards. Using 'precariousness' as a tentative, almost intuitive category, as "a common name for our diverse and singu Lar situations" (Precarias a La deriva, 2004, para. 4), the group met regulariy to perform their own version of "the situationist dérive (...) released" from its bourgeois and masculine connotation of the flâneur in order to be used as a situated, 'open and' multisensoriaf' (...) method" (Tirfer, 2018, para. 1). To produce 'agitation and reflection' and to "enable the collective construction of other life possibilities through the construction of a shared and creative struggle" (Precarias a la deriva, 2004, para. 9). They 'drifted' around the places constituting their precarious working and Living conditions in the fields of communication work, domestic work, catering, nursing, 
"apertura" como este no implicaría también la apertura respecto de esta y otras referencias canónicas? No eliminándolas ni reemplazándolas, sino complejizándolas mediante la apertura respecto de aquellos cuya crítica (sus figuras de pensamiento y acción) está alineada, legitimada y producida por las condiciones prácticas, materiales e ideológicas de la modernidad ilustrada Occidental que no han podido simultáneamente interrogar. La apertura respecto del concepto de agonismo podría conllevar pensarlo junto con la "aposicionalidad" de Stefano Harney y Fred Moten (2013), la "porfía" de Saidiya Hartman (2019), la "epistemología del blues" de Mia Charlene White (2018) o el concepto de "trabajo despierto" de Christina Sharpe (2016), así como junto a conceptos de otros teóricos, cuya radicalidad yace en el rechazo de las propias bases sobre las que comúnmente se hace disponible la crítica: bases creadas a partir de una visión ilustrada del mundo representada por el pensamiento opuesto (oprimido-opresor, amo-esclavo, justo-injusto, etc.).

\section{PUBLICACIÓN VIII}

\section{(BASES COMUNES)}

Elempeño por abrir La academia a un compromiso con el activismo y las activistas feministas e interseccionales a Lo Largo del tiempo y la geografía, trae a La mente La iniciativa denominada Precarias a La deriva. Situado entre La investigación, elactivismo y La comunicación (publicación), este grupo estuvo activo en Madridy sus alrededores desde 2002. Usando La "precariedad" como una categoría tentativa, casi intuitiva, como «un nombre común para nuestras situaciones diversas y singu Lares» (Precarias a (a deriva, 2004, párr. 4), el grupo se reunió regularmente para realizar su propia versión de «La deriva situacionista (...) Liberada de La connotación burguesa y masculina del flâneur para utifizarla como un método situado, "abierto y muStisensoria ["» (Tir Ler, 2018, párr. 1). ELlo, para producir "agitación y reflexión" $y$ «permitir La construcción colectiva de otras posibilidades de vida a través de la construcción de una Lucha compartida y creativa» (Precarias a La deriva, 2004, párr. 9). Fueron "a La deriva" por Los Lugares en que sus precarias condiciones LaboraLes y de vida se constituian en los campos de La comunicación, el trabajo doméstico, el servicio de comida, La enfermería, el trabajo sexual, el trabajo aca démico y La educación. Las Precarias a La deriva no se movian de forma LineaLy progresiva, sino que se desp Lazaban sobre La marcha; no para, no porque, pero tampoco sin las otras; cambiando de formas, vunnerables, inseguras, diversas $y$ diferentes, forizontales, posicionadas:

¿Cómo podemos Guscar nombres comunes y aI mismo tiempo reconocer singularidades, hacer afianzas y comprender Las diferencias? (...) ¿Cómo podemos articuLar nuestra necesidad común sin recurrir a La identidad, sin aplanar u homogeneizar nuestras situaciones?

sex work, scholarship, and education. Precarias a la deriva were moving not Linearly and progressively but navigating on the go; not for, not because but also not without the other; shape-shifting, vu Inerable, insecure, diverse, and different, horizontal, positioned:

Fow can we both seek common names and recognize singularities, make alliances and comprehend difference? (...) Fow shall we articulate our common need without falling back upon identity, without flattening or fomogenizing our situations?

Instead of sitting still to settle alI these doubts, we decided to set off and work them out on the move. (Precarias a La deriva, 2004, paras. 3-4)

Indeed, the positioning, the common vunnerability and precarity, the strategies and values of Precarias a la deriva ${ }^{-}$might also connect the contemporary existing initiatives within their struggle for more open, horizontal, and diverse publishing infrastructures, formats, and practices, and might form the base for new alliances that are increasingly needed. In a time in which high-volume, figh-cost, high-efficiency publishing dominates the evolvements in scholarly communication, struggles in this vein have been continuously precarized (outside of paid working hours), and downplayed (not valued nor incentivized). In a time where Enfightenment ideals of individuation and unity of author and work embedded in scholarly publishing practices and motivations have been increasingly inter Laced with the imperatives and anxieties (publish or perish!) produced by the knowledge market, "the work of the feminist kilfjoy who troubles the waters, works through discomfort, asks hard questions, and commits to practicing forms of research [publishing and communicating] that require 8

Their struggle is not isolated and marginalized within academia (yet still considered formative and therefore central for the academic work of some of the group's members), but unfolds within relationships beyond traditional academic boundaries; by affirmation of a common precarity and vulnerability creating a place for interlinking struggles, forms of resistance and organizational experimentation. more time and effort" (Parker et al., 2017,p. 244), demands more and more strength, and is an increasingly selfdestructive (both in terms of health and career) undertaking. 
En Lugar de quedarnos quietas para resolver todas estas dudas, decidimos partiry resolver Las sobre La marcha (Precarias a la deriva, 2004, párrs. 3-4).

\section{De hecho, elposicionamiento, La uu fnerabilidady La} precariedad común, asi como las estrategias y los valores de Precarias a La deriva ${ }^{8}$ también podrían servir para conectar Las iniciativas contemporáneas en su fucha por infraestructuras, formatos y prácticas editoriales más abiertas, horizontales y diversas, y podrian formar la Gase para nuevas alianzas cada vez más necesarias. En tiempos en que las publicaciones de alto volumen, alto costo y alta eficiencia dominan las formas en que evoluciona La comunicación académica, Luchas como estas han sido continuamente precarizadas (fuera de las horas de 8

Su lucha no está aislada ni marginada dentro de la academia (sin embargo, aún se considera formativa $y$, por lo tanto, central para el trabajo académico de algunas de las personas del grupo), sino que se despliega a través de relaciones que sobrepasan los límites académicos tradicionales. Operan afirmando una precariedad y vulnerabilidad común que crea un lugar para interconectar las luchas, las formas de resistencia y la experimentación organizacional. trabajo remuneradas) y minimizadas (no valoradas ni incentivadas). En momentos en que los ideales de La Ifustración acerca de la entre elautory el trabajo que se encuentran alojados en individualización y fa unidad Las prácticas de publicación y en Las motivaciones académicas se han entre lazado cada vez más con imperativos y ansiedades (ipublicar o morir!) producidos por el mercado del conocimiento, «e trabajo de Ia feminista aguafiestas que perturba Las aguas, trabaja a través de la incomodidad, hace preguntas difíiilesy se compromete a practicar formas de investigación [publicación y comunicación] que requieren más tiempo y esfuerzo» (Parker et al., 2017, p. 244) demanda cada vez más fuerzay se constituye en una empresa cada vez más autodestructiva (tanto en términos de safud como de carrera).

\section{ESTRUCTURAS DE APOYO}

Reconociendo cada vez más que las preguntas sobre apertura, inclusión y equidad se aplican también a las infraestructuras académicas y su gobernanza (Shorish \& Chan, 2019), las iniciativas de publicación lideradas por académicos están fomentando - y a la vez siendo impulsadas - por organizaciones colectivas como el Radical Open Access Collective (Adema \&

\section{SUPPORT STRUCTURES}

Increasingly recognizing that the questions about openness, inclusivity, and equity also apply to scholarly infrastructures and their governance (Shorish \& Chan, 2019), scholar-led publishing initiatives are both fostering and gaining momentum through collectively maintained organizations such as the Radical Open Access Collective (Adema \& Moore, 2018) and the ScholarLed Consortium. Next to scholar-run presses, international scholarly communication infrastructures such as Tuwhera? in New Zealand, the Knowledge Gap at the University of Toronto and AmelicA in Latin America are also part of these networks, which - through fostering horizontal community-led collaboration - aim to generate and sustain diversity within the publishing ecology by offering alternatives to commercial publishing and the conservative versions of open access that are currently being put forward by funders and policy makers (Shorish \& Chan, 2019) while taking into account the local, ideological, and cultural specificity of each member and emphasizing their diversity.

Within their activities, that range from providing advice, information, and support of scholar-led (OA) publishing undertakings to common efforts of legitimizing scholar-led publishing as a valid publishing 'model' and knowledge sharing and exchange among the different members of the collective (Radical Open Access, n.d.), they are supporting alternative models for academic $O A$ publishing that are able to accommodate these, who are not willing nor (financially and technically) able to compete along with the agenda of the neoliberal, managerial university. An important strategical principle in these networks' undertaking is 'non-scaling' (Hall, 2019) in favor of "a plural-

$$
9
$$

Tuwhera (the reo Māori word for 'to be open', 'opening up') aims “to honour Māori reciprocal concepts and ideals such as ako (learning/ teaching), awhi (to cherish), manaaki (hospitality, support, care) and mana tangata (empowerment, humanity)" (Tuwhera, n.d.). istic and multi-polar network, one with a (...) complex, antagonistic and decentred structure" (Hall, 2019, para. 12) rather than aiming 
Moore, 2018) y el Consorcio ScholarLed. Junto a las editoriales dirigidas por académicos, infraestructuras de comunicación académica internacional como Tuwhera? en Nueva Zelanda, The Knowledge Gap en la Universidad de Toronto y AmeliCA en América Latina también forman parte de estas redes, las que, a través de un fomento de colaboración horizontal comunitaria, apuntan a generar y mantener la diversidad dentro de la ecología editorial ofreciendo alternativas 9

Tuwhera (la palabra reo maorí para "estar abierto", "abrirse") busca «honrar conceptos e ideales recíprocos maoríes como ako (aprender/ enseñar), awhi (apreciar), manaaki (hospitalidad, apoyo, cuidado) y mana tangata (empoderamiento, humanidad)» (Tuwhera, s.f.).

a la publicación comercial $\mathrm{y}$ a las versiones conservadoras del acceso abierto que actualmente son promovidas por financistas y policy makers (Shorish y Chan, 2019), teniendo en cuenta la especificidad local, ideológica y cultural de cada miembro y enfatizando su diversidad.

Dentro de sus actividades, que van desde el asesoramiento, la información y el apoyo a las editoriales de acceso abierto dirigidas por académicos hasta los esfuerzos comunes por legitimar la publicación dirigida por académicos como un "modelo" de publicación válido, así como la promoción del intercambio de conocimientos entre los diferentes miembros del colectivo (Radical Open Access, s.f.), están apoyando modelos alternativos para un tipo de publicación académica de acceso abierto que pueda adaptarse a ellos, y que no están dispuestos (ni financiera ni técnicamente) a competir con la agenda de la universidad neoliberal y gerencial. Un principio estratégico importante en estas redes es el de "no escalar" (Hall, 2019), favoreciendo «una red pluralista y multipolar, con una (...) estructura compleja, antagónica y descentrada» (Hall, 2019, párr. 12) en lugar de competir a través de un escalamiento con las redes de información globalmente centralizadas y unificadas.

PUBLICACIÓN IX (COMO THRIVAL)

Además de ofrecer infraestructuras materiales y organizativas, estas redes también proporcionan infraestructuras relacionales de cuidado que, al menos hasta cierto punto, son capaces de «absorber los go Lpes de nuestra agresiva necesidad de que el mundo se acomode a nosotrosy a nuestra to compete with the globally unified centralistic information networks through scale.

PUBLISHING IX (AS THRIVAL)

Besides material and organizational infrastructures, these networks also offer relational infrastructures of care that - at least to a certain extent - are able to "absorb the blows of our aggressive need for the wor Id to accommodate us and our resistance to adaptation and that, at the same time, hold out the prospect of a world worth attaching to that's something other than an old hope's bitter echo" (BerLant, 2016, p. 414). While taking into account the Local, ideological, and cultural specificity of each member and emphasizing their diversity, these infrastructures allow them to collectively pursue publishing (not for, not because but also not without the other) as a "pedagogy of unlearning while living with the malfunctioning world, uu nnerable confidence, and the rolling ordinary" (Ber Lant, 2016, p. 396), as a thinking and re-orienting through doing (a doing scholarship that is also undoing scholarship) opening out across, not just discip Iines and space, Gut also time.

Publishing Like this might be seen as 'thrival'. The word was coined by Andrés L. Fermández and Shani Crowe in their work 'Thrival Geographies (In My Mind I See a Line)' for the us Pavilion at Venice Architecture Biennale 2018. Thrival is directed against the narrative of survival, which is also always one of subjugation, whereas a narrative of thrival points beyond survival to thriving towards the affirmation of a potentiality within the 'malfunctioning wor Id' (Ber Lant, 2016).

\section{PUBLISHING $\mathrm{X}$}

If I were to Iive my life / in cattish forms / in scaffolds of skin and whiskers / at the bottom of a pond / and you were to come by one evening / when the moon was shining / down into my dark fome / and stand there at the edge of my affection / and think, "It's beautifuS / here by this pond. I wish somebody loved me." / I'd Love you and be your catish / friend and drive such Lonely / thoughts from your mind / and suddenly you would be / at peace, / and askyourself, "I wonder / if 
resistencia a adaptamosy, a I mismo tiempo, ofrezcan La perspectiva de un mundo al que valga La pena adherirse, a go más que el amargo eco de una vieja esperanza» (BerLant, 2016, p. 414). Teniendo en cuenta La especificidad Local, ideo Lógica y cultural de cada uno dé sus miembrosy enfatizando su diversidad, estas infraestructuras permiten ejercer colectivamente la publicación (no para, no porque, pero tampoco sin el otro); como una upedagogía del desaprendizaje, mientras se vive con un mundo que funciona mal, con una confianza uufnerabley una ordinaria rutina» (Ber [ant, 2016, p. 396); como un pensamiento y una forma de reorientación a través del hacer (un trabajo académico de hacer que también es de deshacer), abriendo no solo las disciplinas y el espacio, sino también el tiempo.

Una forma de publicar como esta podría verse como thrival. La palabra en inglés thrival fue acuñada por Andrés L Flemándezy Shani Crowe en su trabajo "Thrival Geographies (In My Mind I See a Line)" para elpabellón de ez. uu. en La Bienal de Arquitectura de Venecia 2018. Thrival va en contra de la narrativa de supervivencia, que siempre implica también subyugación. Una narrativa de thrival, en cambio, supera La supervivencia para Llegar a La prosperidad: hacia la afirmación de una potencialidad en el contexto de un "mundo que funciona maI" (Ber Lant, 2016).

\section{PUBLICACIÓN X}

Si tuviera que vivir mi vida / en formas de pez gato / en andamios de piely bigotes / en elfondo de un estanque / y fueras a venir por aquí una tarde / cuando La Luna brille / aqui abajo en mi oscuro hogar / y te quedaras alli, al borde de mi cariño / pensando: "Es hermoso / aquí cerca de este estanque. Desearía que aLguien me amara». / Te amaríay sería pez gato / tu amigo, y haría desaparecer de tu mente / pensamientos tan solitarios / y de repente estarias / en paz/ $y$ te preguntarias: "¿habrá a Gún pez gato / en este estanque? Parece / un Lugar perfecto para ellos» (Brautigan, 1989).10

\section{PUBLICACIÓN XI}

(CONTAMINACIÓN COMO THRIVAL)

La capacidad de pensary actuar juntos mientras se promueven condiciones que permitan permanecer separados se basa no solo en La pregunta acerca de qué relaciones están 10 permitidas o deshabilitadas dentro de la Gracias a Jamie Allen. publicación (y cómo se consigue esto) y there are any catfish / in this pond? It seems Like / a perfect place for them. ${ }^{10}$ (Brautigan, 1989)

10

Thanks to Jamie Allen.

PUBLISHING XI

(CONTAMINATION AS THRIVAL)

The ability of thinking and acting together while allowing each to remain separate is predicated not only on the question of what relations are allowed or disabled within publishing (and how this is done) and with whom, but also on the question about the nature of these relationships (Craig et al., 2011) and their performance by every member of the collectivity. In this regard, the drawing on another relation emerging from an opening out from the narrow conception of scholarly work (as something conditioned by its affliation to institutional academia) might be helpful: namely the one with Kitchen Table: Women of CoLor Press. Its founders - among them, the activists and scholars Barbara Smith, Beverly Smith, and Audre Lord, and the Chicana activists and academics Cherrie Moraga and GLoria Anzaldúa - were engaged in a common struggle of confronting and changing the habitual behavior that contributed to (Glack) women's oppression (Adair \& Nakamura, 2017; Fernandezet af., 2002; Moraga \& Anzaldúa, 1983; B. Smith, 1989) through their commitment "to producing work of high artistic quality that simultaneously contributes to the liberation of women of color and of allpeople" (B. Smith, 1989, p. 12). The communality between these distinct and distant feminists (Adair \& Nakamura, 2017; Moraga \& Anzaldúa, 1983; B. Smith, 1989), women of color artists and writers working outside or on the margins of academia was considered an achievement through an active engagement with solidarity, as a commitment to diversity and individual as well as collective transformation:

\footnotetext{
It is not a given between us - Chicana and Black - to come to see each other as sisters. This is not a given. I keep wanting to repeat over and over, and over again the pain and shock of difference, the joy of commonness, the exhilaration of meeting through incredible odds against it. But the passage is
} 
con quién, sino también en La pregunta sobre La natura leza de estas relaciones (Craig et al., 2011) y La forma en que cada miembro de la colectividad las produce. En este sentido, podría ser útif delinear otra relación a partir de una apertura de la concepción estrecha del trabajo académico (como algo que está condicionado por su afliación a las instituciones académicas), a saber, La relación que establece Kitchen Table: Women of CoLor Press. Sus fundadoras -entre ellas, Las activistas y académicas Barbara Smith, Bever Ly Smithy Audre Lord, asi como Las activistas y académicas chicanas Cherrie Moragay GLoria AnzaLdúa-se involucraron en una Lucha común destinada a confrontary cambiar ef comportamiento acostumbrado que contribuía a La opresión de Las mujeres (negras) (Adair \& Nakamura, 2017; Fernandez et aL., 2002; Moraga \& AnzaLdúa, 1983; B. Smith, 1989) a través de su compromiso «por producir trabajos de afta calidad artística que contribuyan simultáneamente a Ia Liberación de Las mujeres de colory de todas Las personas» (B. Smith, 1989, p.12). La comunalidad entre estas feministas distintasy distantes (Adair \& Nakamura, 2017; Moraga \& Anzaldúa, 1983; B. Smith, 1989), mujeres de color, artistas y escritoras que trabajaban fuera o aL margen de la academia, se consideró un Logro, especialmente por su activo compromiso con La solidaridad, La diversidady la transformación individuafy colectiva:

No se daba por sentado que nosotras, chicanas y negras, pudiésemos vernos como hermanas. Esto no sucede por si solo. Sigo queriendo repetir una y otra vez, y otra vez, por sobre el do Lor y fa conmoción de la diferencia, La alegría de lo común, el regocijo de encontramos a través de todas las probabilidades en contra. Porque el camino es a través dé, no por arriba, no por abajo, no alrededor, sino a través de (Moraga, 1983, p.xiv).

Reconocieron que «para cambiar el mundo tenemos que cambiamos a nosotras mismas, incluso a veces nuestras convicciones más rígidas (...) Todas somos responsables de lo que está sucediendo en La calle, a sur de La frontera o a L tro Lado del océano» (Moraga, 1983). Titchen Table se estaba abriendo desde su Lucha feminista negra hacia Lo "blanco, heterosexual, queer, masculino» (Moraga, 1983), y al igual que Precarias a la deriva (en su afirmación de su precariedad común), estaban reconociendo que un proyecto colectivo de "construcción del mundo" debe «comenzar desde el imperativo through, not over, not by, not around, but through" (Moraga, 1983 , p.xiv).

They acknowledged that "to change the world, we have to change ourselves - even sometimes our most cherished 6lock-hard convictions (...) We are each accountable for what is happening down the street, south of the border or across the sea" (Moraga, 1983). Kitchen Table press were opening out from their black feminist struggle towards "white, straight, queer, male" (Moraga, 1983), and just as Precarias a la deriva (within their affirmation of their common precarity) they were recognizing that a common project of 'world-6uifding' must "start from the imperative to reconstruct the wor Id in common (...) it cannot start from the assumption that I ampurer than my neigh6or" (MGembe \& Nilsen, 2019).

For those involved in contemporary feminist and intersectiona Spublisfing undertakings, this would imply - within all aspects of their scholarly practice - an acknow ledgement that also the Westerm body, as the totality of those that prefigured and were formed by a Western theoretization and experience of modernity, besides violating others, has maimed itself (with all the consequences this may effect).

It would be a misleading conclusion to, from here, enter - as Achille Mbembe says - the "competition about who has suffered more on the spiralling scale of victimization" (MGembe \& Nifsen, 2019). These mobilizations and framings,

Although fought in the name of equality and justice (...) might end up reenacting a sectarian Logic of enclosure, underpinned as they are by flawed notions of identity, gender or culture as spaces of protection and immunity, as borders which allow for a closing off from 'those who are not as radical as us'. (Mbembe \& Nilsen, 2019)

Apublishing evolving on these premises would be a publishing as identity politics or an identity politics as publisfing, an eternal fight for representation, an ideologicalstand-off between affirmation and critique, not resolving but relocating 
de reconstruir el mundo en común (...), no puede comenzar desde La suposición de que soy más pura que mi vecina» (Mbembe \& Nifsen, 2019).

Para quienes participan en emprendimientos editoriales feministas e interseccionales contemporáneos, esto imp iccaría, entre todos los aspectos de su práctica académica, reconocer que también el cuerpo occidental - como la totalidad de aquellos que prefigurarony se formaron por una teorización occidentaly una experiencia de modernidad-, además de vioLar a otros, se ha mutilado a si mismo (con todas las consecuencias que esto pueda tener).

Sería una conclusión engañosa, a partir de aquí, querer entrar en la «competencia sobre quién ha sufrido más en la esca la de vietimización», como dice Achille Mbembe (Mbembe \& Nifsen, 2019). Aun cuando estas movilizaciones y marcos

Luchan en nombre de La igualdady la justicia (...), podrian terminar reenactando una Lógica sectaria de encierro, sustentadas, como lo están, por nociones defectuosas de identidad, género o cultura como espacios de protección e inmunidad, como fronteras que permiten aislarse de "aquellas que no son tan radicales como nosotras" (M Mbembe \&Dilsen, 2019).

Una publicación que evolucione a partir de estas premisas sería una manera de publicar como politica identitaria o una política identitaria como forma de pubficar, una eterna Lucha por La representación, un enfrentamiento ideológico entre afirmación y crítica que no resolvería sino que reubicaría los desequilibrios de poder y las discriminaciones embebidos en Las estrategias comerciales de Lapublicación abierta.

En contraposición a esto, una publicación relacional que toma La impureza común como base relacionaL - sin negar La diferencia en el reconocimiento financiero, aca démico y social, ni el grado de vu nnerabilidad entre Los académicos contemporáneos, como tampoco entre los aca démicos contemporáneos y el activismo feminista e interseccional fuera de La academia-, implicaría que eL "yo" está abierto a la posibilidad de convertirse en un otro: eL "yo" no se concibe como un estatus corporalmente transfigurado y singu far, ni como una simple cuestión de "ser", sino como un proceso continuo de "convertirse". Un convertirse que está haciéndose constantemente, un proceso the power disbalances and discriminations embedded in commercial $O A$ strategies.

Contrary to this, relational publisfing taking a common impurity as relational base - without negating the difference in financial, academic, and social recognition and the degree of un inerability between contemporary academics, but also between contemporary academics and feminist and intersectional activism outside of academia - would imply that ' $T$ ' is open to the possibility of becoming (an) other: The ' $T$ ' is not conceived of as a bodily transfixed and singuLar status, nor as a matter of mere 'being' but as an ongoing process of 'becoming'. A becoming that is constantly in the making, an open-ended and inherent $y$ collaborative process of transformation and movement in relation to, towards and by interaction and inter-connectedness with multiple others - beings, matter, machines. "It's this space in-Getween, the space we give, the space we are given and the space we take or that is taken from us," as my friend, collaborator and co-thinker Nina Jäger wrote in one of her wonderfu emails, "immeasurable distances, the vastness of a fingertip. (...) being-with as an opening towards the unknown - or, the other/self, beingbetween or being-in-common (...) a missing space of being-between or being-in-common." $\square$ 
abierto e inferentemente colaborativo de transformacióny movimiento en relación con, dirigido hacia y habilitado por La interaccióny la interconexión con múltiples otros: seres, materia, máquinas. «Es este espacio intermedio, el espacio que damos, el espacio que recibimosy el espacio que tomamos o que nos quitan», como escribió mi amiga, colaboradoray co-pensadora Jina Jäger en uno de sus maravilfosos correos electrónicos: «distancias inconmensurables, La inmensidad de La punta de un dedo. (...) elser-con como una apertura hacia Lo desconocido: o, e[ otro/mismo, ser-entre o ser-en-común (...) un espacio perdido de ser-entre o ser-en-común». \.

\section{REFERENCIAS / REFERENCES}

ACKER, K. (1990). Dead Doll Humility. Postmodern Culture, 1(1). Retrieved from http://pmc.iath.virginia.edu/text-only/ issue.990/acker.990

ADAIR, C., \& NAKAMURA, L. (2017). The Digital Afterlives of This Bridge Called My Back: Woman of Color Feminism, Digital Labor, and Networked Pedagogy. American Literature, 89(2), 255-278. https://doi. org/10.1215/00029831-3861505

ADEMA, J. (2018). The Poethics of Openness. In J. Adema, K. Marczewska, F. McDonald, \& W. Trettien (Eds.), The Poethics of Scholarship (pp. 16-23). Post Office Press.

ADEMA, J. (2019). The Ethics of Emergent Creativity: Can We Move Beyond Writing as Human Enterprise Commodity and Innovation? In J. J. Kember \& S. Kember (Eds.), Whose Book is it Anyway? A View from Elsewhere on Publishing, Copyright and Creativity (pp. 6590). Open Book Publishers. https://doi.org/10.11647/ ОВР.0159

ADEMA, J., \& MARCZEWSKA, K. (2019). Post Publishing. Retrieved from www.post-publishing.org

ADEMA, J., \& MOORE, S. A. (2018). Collectivity and Collaboration: Imagining new Forms of Communality to Create Resilience in Scholar-led Publishing. Insights, 31, 33 : 1-11. https://doi.org/10.1629/uksg.399

ADEMA, J., \& STONE, G. (2017, September 20). Taking Back Control: The New University and Academic Presses that are Re-Envisioning Scholarly Publishing. LSE Impact Blog. Retrieved from https://blogs.Ise. ac.uk/impactofsocialsciences/2017/o9/20/ taking-back-control-the-new-university-andacademic-presses-that-are-re-envisioningscholarly-publishing/

AHMED, S. (2017). Living a Feminist Life. Duke University Press.

Álvarez solis, A. O. (2018). Geopolíticas del conocimiento y lengua universitaria. The Managerial Impasse of the Latin American University. In Culture Machine (Ed.), The Geopolitics of Open (pp. 26-34). Post Office Press. ARBUCKLE, A., \& MAXWELL, J. (2019). Modelling Open Social Scholarship Within the INKE Community. KULA: Knowledge Creation, Dissemination, and Preservation Studies, 3(1), 2. https://doi.org/ org/10.5334/kula.15

BARAD, K. (1997). Meeting the Universe Halfway: Realism and Social Constructivism without Contradiction. In L. Hankinson Nelson \& J. Nelson (Eds.), Feminism, Science, and the Philosophy of Science (pp. 161-194). Kluwer Academic.

BELL, K. (2019). Communitas and the Commons: The Open Access Movement and the Dynamics of 
Restructuration in Scholarly Publishing. Anthropology

Today, 35(5), 21-23. https://doi.org/10.1111/1467-

8322.12530

BERLANT, L. (2016). The Commons: Infrastructures for Troubling Times". Environment and Planning $D$ : Society and Space, 34(3), 393-419. https://doi. org/10.1177/0263775816645989

BRAUtIGAN, R. (1989). The Pill Versus the Springhill Mine Disaster Houghton Mifflin.

CHRISTEN, K. (2012). Does Information Really Want to be Free? Indigenous Knowledge Systems and the Question of Openness. International Journal of Communication, 6 , 2870-2893.

CRAIG, C. J., TURCOTTE, J. F., \& COOMBE, R. J. (2011). What's Feminist About Open Access? A Relational Approach to Copyright in the Academy. Feminists@law, 1(1), 1-25

CRAWFORD, W. (2002). Free Electronic Refereed Journals: Getting Past the Arc of Enthusiasm. Learned Publishing, 15(2), 117-123. https://doi. org/10.1087/09531510252848881

FERNANDEZ, M., WILDING, F., \& WRIGHT, M. M. (Eds.). (2002). Domain Errors!: Cyberfeminist Practices. Autonomedia.

GRAY, E., TROTTER, H., \& WILLMERS, M. (2012). Scholarly Communication in Africa: Aligning Strategy and Technology for Increased Visibility of Southern African Research. Retrieved from www.academia.edu/2898170/ Scholarly_Communication_in_Africa_Aligning_ Strategy_and_Technology_for_Increased_Visibility_of_ Southern_African_Research

HALL, G. (2008). Digitize this Book! The Politics of New Media, or Why we Need Open Access Now. University of Minnesota Press.

HALL, G. (2019, February 18). Media Gifts-The Left Can't Meme? Retrieved from http://garyhall.squarespace.com/ journal/2019/2/18/the-left-cant-meme.html

HARAWAY, D. J. (1988). Situated Knowledges: The Science Question in Feminism and the Privilege of Partial Perspective. Feminist Studies, 14(3), 575-599.

HARAWAY, D. J. (2016). Staying with the Trouble: Making Kin in the Chthulucene. Duke University Press.

HARNEY, S., \& MOTEN, F. (2013). The Undercommons: Fugitive Planning \& Black Study. Autonomedia.

HARTMAN, s. (2019). Wayward Lives, Beautiful Experiments: Intimate Histories of Social Upheaval. W. W. Norton \& Company.

HEDLUND, T., GUSTAFSSON, T., \& BJÖRK, B.-C. (2004). The Open Access Scientific Journal: An Empirical Study. Learned Publishing, 17(3), 199-209. https://doi. org/10.1087/og5315104323159621

ноокS, в. (1990). Postmodern Blackness. Postmodern Culture, 1(1). Retrieved from http://pmc.iath.virginia.edu/textonly/issue.990/hooks.990

IYER SIDDIQI, A. (2018, July). Writing With: Togethering,
Difference, and Feminist Architectural Histories of Migration. E-Flux Architecture. Retrieved from www.e-flux.com/architecture/structuralinstability/208707/writing-with/

JONG, S. DE, ICAZA, R., VÁZQUEZ, R., \& WITHAECKX, S. (2017). Editorial. Tijdschrift Voor Genderstudies, 20(3), 227-231(5). https://doi.org/10.5117/ TVGN2017.3.JONG

JoY, E. (2017, May 7). Here Be Monsters: A Punctum Publishing Primer. Punctumbooks. Retrieved from https://punctumbooks.com/blog/here-bemonsters-a-punctum-publishing-primer/

KeMBer, s. (2014). Why Write? Feminism, Publishing and the Politics of Communication. New Formations, 83, 99-116. https://doi.org/10.3898/ NEWF.83.06.2014

KIESEWETTER, R., \& KOLB, L. (2019). Annotating Publishing. Publishing as Institutent Practice. [Seminar reader, workbook]. Critical Media Lab (IXDM) HGK FHNW Basel.

KNECHT, S. DE. (2019, November 6). Leaked Document on Elsevier Negotiations Sparks Controversy. ScienceGuide. Retrieved from www. scienceguide.nl/2019/11/leaked-document-onelsevier-negotiations-sparks-controversy/

LARIVIÈRE, V., HAUSTEIN, S., \& MONGEON, P. (2015). The Oligopoly of Academic Publishers in the Digital Era. PLOS ONE, 10(6), e0127502. https://doi. org/10.1371/journal.pone.0127502

LATOUR, B. (2005). From Realpolitik to Dingpolitik. Or How to Make Things Public. In B. Latour \& P. Weibel (Eds.), Making Things Public: Atmospheres of Democracy (pp. 14-27). MIT Press.

LATOUR, B., \& WOOLGAR, S. (1986). Laboratory Life: The Construction of Scientific Facts. Princeton University Press.

LEYVA, X., ALONSO, J., HERNÁNDEZ, R. A., ESCOBAR, A., KOHLER, A., CUMES, A., SANDOVAL, R., SPEED, S., BLASER, M., KROTZ, E., .. \& MIGNOLO, W. (2015). Prácticas otras de conocimiento(s) entre crisis, entre guerras (Tomo 3). Cooperativa Editorial Retos.

MALIK, R. (2008). Horizons of the Publishable: Publishing in/as Literary Studies. ELH, 75(3), 707-735.

MARCZEWSKA, K. (2018). The Horizon of The Publishable in/as Open Access: From Poethics to Praxis. In J. Adema, K. Marczewska, F. McDonald, \& W. Trettien (Eds.), The Poethics of Scholarship (pp. 6-13). Post Office Press.

Mbembe, A., \& NILSEN, T. T. (2019, September 5). Thoughts on the Planetary: An Interview with Achille Mbembe. Retrieved from www.newframe.com/thoughtson-the-planetary-an-interview-with-achillembembe/ 
MÉNDEZ COTA, G. (2018). On Being Heard: The Content and the Form of Geopolitics. In Culture Machine (Ed.), The Geopolitics of Open (pp. 16-25). Post Office Press.

Moore, S. (2019a). Common Struggles: Policy-Based vs. ScholarLed Approaches to Open Access in the Humanities [PhD Dissertation, King's College London]. Retrieved from https://hcommons.org/deposits/item/hc:24135/

MOORE, S. (2019b). Revisiting 'the 1990s Debutante': Scholarled Publishing and the Pre-history of the Open Access Movement (Postprint). Journal of the Association for Information Science and Technology, 2019, 1-11. https://doi. org/10.1002/asi.24306

MORAGA, C. (1983). Refugees of a World on Fire. Foreword to the 2nd edition. In C. Moraga \& G. Anzaldúa (Eds.), This Bridge Called My Back: Writings by Radical Women of Color. Kitchen Table.

MoragA, C., \& ANZALdúA, G. (Eds.). (1983). This Bridge Called My Back: Writings by Radical Women of Color. Kitchen Table. MoufFE, C. (2014). Agonistik: Die Welt politisch denken (R. Barth, Trans.). Suhrkamp Verlag.

PARKER, P. S., SMITH, S. H., \& DENNISON, J. (2017). Decolonising the Classroom. Tijdschrift Voor Genderstudies, 20(3), 233-247. https://doi.org/10.5117/TVGN2017.3.PARK POVINELLI, E. A. (2011). The Woman on the Other Side of the Wall: Archiving the Otherwise in Postcolonial Digital Archives. Differences, 22(1), 146-171. https://doi. org/10.1215/10407391-1218274

PRECARIAS A LA DERIVA. (2004). Adrift through the Circuits of Feminized Precarious Work. European Institute for Progressive Cultural Polices. Retrieved from https:// eipcp.net/transversal/o704/precarias1/en.html

PUIG DE LA BELLACASA, M. (2017). Matters of Care: Speculative Ethics in More Than Human Worlds. University of Minnesota Press.

RADICAL OPEN ACCESS. (n.d.). Building Horizontal Alliances. Retrieved from http://radicaloa.disruptivemedia.org. uk/about/

READINGS, B. (1999). The University in Ruins. Harvard University Press.

SHARPE, C. E. (2016). In the Wake: On Blackness and Being. Duke University Press.

SHORISH, Y., \& CHAN, L. (2019, October 22). Co-creating Open Infrastructure to Support Diversity and Equity. ScholarLed Blog. Retrieved from https://blog.scholarled.org/cocreating-open-infrastructure-to-support-epistemicdiversity-and-knowledge-equity/

SHUKAITIS, S. (2014, June). Toward an Insurrection of the Published? Ten Thoughts on Ticks \& Comrades. European Institute for Progressive Cultural Polices. Retrieved from https://eipcp.net/transversal/o614/shukaitis/en.html

SIMPSON, L. B. (2011). Dancing on Our Turtle's Back: Stories of Nishnaabeg Re-Creation, Resurgence, and a New Emergence. ARP Books.
SMITH, в. (1989). A Press of Our Own Kitchen Table: Women of Color Press. Frontiers: A Journal of Women Studies, 10(3), 11-13. https://doi. org/10.2307/3346433

SMITH, L. T. (1999). Decolonizing Methodologies: Research and Indigenous Peoples. Zed Books.

STENGERS, I. (2005). Introductory Notes on an Ecology of Practices. Cultural Studies Review, 11(1), 183-196. https://doi.org/10.5130/csr.v11i1.3459

Stengers, I., \& Bordeleau, E. (2011). The Care of the Possible: Isabelle Stengers interviewed by Erik Bordeleau. Scapegoat, 1, 12-27.

THOBURN, N. (2016). Anti-Book. University of Minnesota Press.

TIRLER, J. (2018). Precarias a la deriva. Krisis, 2. Retrieved from https://krisis.eu/precarias-a-la-deriva/

TKACZ, N. (2012). From Open Source to Open Government: A Critique of Open Politics. Ephemera: Theory and Politics in Organization, 12(4), 386-405.

TUWHERA. (n.d.). About Tuwhera. Retrieved from https:// tuwhera.aut.ac.nz/about-tuwhera

WARNER, M. (2002). Publics and Counterpublics (abbreviated version). Quarterly Journal of Speech, 88(4), 413-425. https://doi. org/10.1080/00335630209384388

WHITE, M. C. (2018). Love: A Blues Epistemology from the Undercommons [Keynote lecture during Beyond Change Conference]. FHNW HGK Basel.

WILLIN SKY, J. (2006). The Access Principle. MIt Press. WIN D GÄTtER, C. (2016). Wissenschaft als Marke. Brinkmann \& Bose. 